\title{
AVALIAÇÃO DO ESTRESSE OXIDATIVO AGUDO APÓS TRAUMA CIRÚRGICO REALIZADO EM TECIDO ÓSSEO DE RATOS WISTAR.
}

Tese apresentada ao Instituto de Ciências Biomédicas da Universidade de São Paulo, para obtenção do Título de Doutor em Ciências MorfoFuncionais.

Marcos Barbosa Salles

Orientador- Prof. Dr. Bruno König Junior

São Paulo

2007 


\section{RESUMO}

Este trabalho teve como objetivo inicial avaliar o estresse oxidativo agudo póstrauma cirúrgico, pela ativação de uma endonuclease sensível ao estresse, a NF$\mathrm{kB}$, avaliada em cortical óssea de ratos Wistar. Para isto, a técnica de inclusão em acrílico glicolmetacrilato (Technovit $₫ 7200$ VLC) foi modificada, com a intenção de estas amostras reagirem com 0 anticorpo, utilizando-se 0 método de imunohistoquímica, pela técnica de streptavidina-biotina. Foram utilizados 140 animais machos, pesando, em média, $350 \mathrm{~g}$, divididos em grupos. No Grupo determinação da curva de ativação (1), foi determinado o pico de ativação da NFkB em cortical óssea de ratos Wistar, que se estabeleceu em seis horas; no grupo Irrigado (2), observou-se uma redução da ativação da NF-kB na posição zero na região periostal, porém, os resultados estatísticos não indicaram significância em relação ao controle (animais do grupo determinação da curva de ativação, nos quais o pico de ativação da NF-kB em cortical óssea foi atingido em 6h); no grupo implantes de titânio (3), observou-se uma redução da ativação da NF-kB por toda a cortical óssea, porém, a queda de ativação também não foi significativa em relação ao controle; no grupo adrenalectomizados (4), os resultados foram similares aos grupos anteriores, porém, foi observado um aumento da ativação positiva significativo na região do joelho; no grupo Dexamentasona (5), observouse um aumento significativo da imunorreatividade positiva da referida endonuclease em cortical óssea de ratos Wistar; e, finalmente, no grupo Composto Orgânico (6), observou-se uma redução significativa desta endonuclease comparativamente aos demais grupos. Neste trabalho, também foi observado que a imunorreatividade para a NF-kB não se restringiu à região lesada, mas se estendeu por toda a cortical óssea, aumentando na região do joelho.

Conclui-se, então, neste estudo: 1- que o método de imunohistoquímica pode ser aplicado em tecido ósseo não descalcificado, incluído em glicolmetacrilato (Technovit@ 7200 VLC); 2- os implantes de titânio, neste período de poucas horas, 
não permanecem em sua posição, dificultando a avaliação da ação de um biomaterial com 0 tecido ósseo adjacente utilizando 0 método de imunohistoquímica; 3- o composto orgânico foi efetivo na redução da imunorreatividade da NF-kB, reduzindo significativamente a ativação da NF-kB, em cortical de ratos Wistar; 4- e, finalmente, que a utilização da Dexametasona como antiinflamatório em tratamentos pré-cirúrgicos precisa ser melhor estudada.

\section{Palavras-Chave:}

Tecido Ósseo, Reparação, Inflamação, NF-kB, Estresse Oxidativo, Imunoistoquímica 


\begin{abstract}
This work had as an initial objective to evaluate the acute oxidative stress after surgical trauma, through the activation of NF-KB, which is a stress sensitive endonuclease, studied on Wistar rats' cortical bone.For this purpose the technique for inclusion with glycolmethacrilate acrylic (Technovit ${ }^{\circledR}$ 7200VLC) was modified in order to promote a reaction between the antibody and the studied samples using an immunohistochemical method known as a streptavidina-biotine technique.In this study 140 male rats, weighting approximately $350 \mathrm{~g}$ were divided in 6 groups: 1 . In the group where the purpose was to determine the curve of activation, peak of activation of NF-KB was determined on Wistar rats' cortical bone in the period of six hours. 1. In the group where irrigation was used, a reduction of NF-KB activation was noticed in the zero position, in the periosteal region. Despite these results it was not statically significant when compared to the control group (6h group for the determination of the curve activation). 2. In the group where Ti implants were used a reduction in the NF-KB activation was noticed on the entire cortical bone surface but it was not significant compared to the control group. 3. In the adrenalectomized group the results were similar to those in groups previously presented although a significant increase was noticed in the knee area. 4. The dexamethasone group presented a significant increase in the positive immunoreactivity of this endonuclease on Wistar rats' cortical bone. 5 . In the organic compound group a significant decrease of the positive immunoreactive endonuclease compared to the other groups. In the present work, it was noticed that the immunoreactivity of the NF-KB was not restricted to the injured region, but the reaction was extended to the entire cortical bone with an increase in the region of the knee. Conclusions: 1 . The immunohistochemical method may be applied to non-decalcified bone tissue and included to glycolmethacrilate (Technovit ${ }^{\circledR}$ 7200VLC). 2. The titanium implants do not present bone integration at a period of just few hours to its insertion causing some difficulties to evaluate a biomaterial and the adjacent bone area using the immunochemistry method. 3. The organic compound was effective in the reduction of the immunoreactivity of NF-KB
\end{abstract}


significantly reducing the activation of the endonuclease immunoreactivity on Wistar rats' cortical bone. 4. More studies are required to the use of Dexamethasone as anti-inflammatory medicament on the surgical treatments.

Key Words:

Bone, Repair, Inflammation, NF-kB, Oxidative Stress, Immunohistochemical 
1 INTRODUÇÃO 


\subsection{Introdução}

Pesquisas relacionadas ao tecido ósseo tomaram um grande impulso com o advento dos implantes intra-ósseos, quando Brånemark, em 1969, propôs a utilização de cilindros de titânio inseridos em mandíbulas e maxilas para um posterior restabelecimento protético. O protocolo cirúrgico inicial proposto por Brånemark foi a inserção de cilindros apenas na região do mento, mas com o desenvolvimento das técnicas cirúrgicas este protocolo se estendeu para toda a cavidade oral, com grande auxílio da enxertia óssea; de forma que as práticas anteriormente utilizadas em ortopedia foram adaptadas para a região da boca, com o intuito de tentar restabelecer a morfologia do tecido ou, muitas vezes, criar condições para a instalação de implantes, como a técnica de elevação do seio maxilar, enxertia óssea inlay e onlay, entre outras. Para tanto, são utilizados recursos mecânicos como a distração osteogênica, técnica ortopédica adaptada para os maxilares; ou a estimulação da neoformação óssea através da enxertia e do emprego de materiais que induzam a formação óssea.

Ultimamente, estas pesquisas têm se voltado para a incorporação do enxerto ao tecido ósseo adjacente, e mais recentemente ainda, aos mecanismos moleculares que integram a fisiologia deste processo. UDIPI et al. (2000) discutiram os eventos que envolvem o processo de reparo após a inserção dos implantes, suas inter-relações com o processo inflamatório agudo e/ou crônico, a formação de uma fibrose local orquestrada pelo processo inflamatório e de macrófagos na interface implante e/ou biomaterial. Os autores abordaram as falhas de enxertos e implantes e como evitá-las ou solucioná-las, propondo como estratégia a inclusão de um componente do sistema de defesa do organismo ao enxerto - uma enzima sintética chamada de superóxido dismutase, que age no sistema redox, transferindo elétrons de espécies reativas de oxigênio (Radical Oxigen Species - ROS) para a formação de elementos não agressivos ao sistema, como $\mathrm{H}_{2} \mathrm{O}$ e $\mathrm{O}_{2}$.

A partir do desenvolvimento dos implantes intra-ósseos para reabilitações implanto-protéticas orais, houve a necessidade de melhor compreensão do comportamento do tecido ósseo. Respaldadas nos avanços das análises biológicas, várias técnicas estão sendo desenvolvidas para este fim, unindo as disciplinas clínicas e básicas para que os pacientes tenham uma recuperação melhor e mais rápida. 
$\mathrm{O}$ isolamento de células específicas de um tecido muitas vezes permite avaliar particularidades existentes neste, porém é imprescindível a compreensão da constituição do mesmo sob uma perspectiva geral. São necessárias, portanto, a micro e a macro visões - ou seja, a análise dos pontos de vista tanto específico quanto geral - dos acontecimentos que se interpõem e contrapõem em um determinado mecanismo ou processo, para que se possa alcançar o controle do mesmo e direcioná-lo para uma condição favorável.

O presente trabalho teve como ponto de partida os resultados morfológicos obtidos anteriormente por Salles (2001), apresentados em dissertação de mestrado concluída no Departamento Anatomia do Instituto de Ciências Biomédicas da Universidade de São Paulo (ICB/USP) em 2001, que indicaram efetiva participação de um composto orgânico, então desenvolvido, no processo de reparo; reduzindo significativamente a agressão produzida por um polímero (Poliuretana de Mamona Poliol) frente aos tecidos adjacentes (Fig. 01).

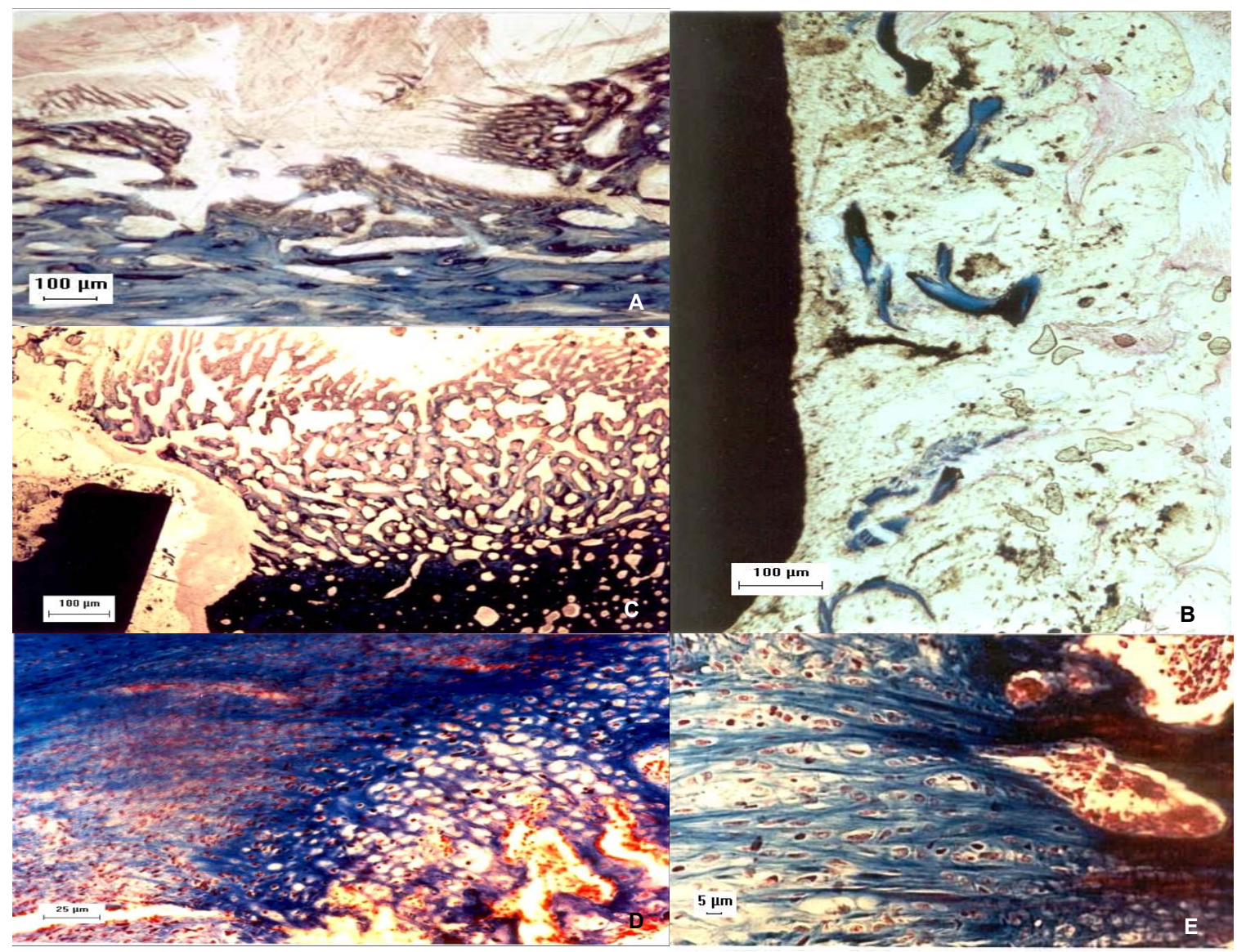

Fig. 01- As imagens acima representam resultados obtidos na referida dissertação de mestrado. Em A, nota-se a completa expulsão do material enxertado (Poliol). As imagens B,C,D e E indicam alteração de comportamento do polímero frente aos tecidos adjacentes com a adição do composto orgânico. Nas imagens B e C, é possível notar neoformações ósseas na região medular e periostal, indicando que, com o acréscimo do composto orgânico, houve uma redução da agressão proporcionada pelo polímero. Em D, é possível observar a interposição de um tecido cartilagíneo entre o fibroso e a neoformação óssea, o que indica uma ossificação transcondróide. Em E, esta formação cartilagínea não é notada, porém a imagem indica a neoformação de uma espícula óssea a partir do tecido fibroso. 
Em outro trabalho complementar realizado em coelhos, o uso do composto orgânico foi dissociado da matriz de polímero e associado a uma matriz de gelatina, menos agressiva, e os resultados observados indicaram uma expressiva neoformação óssea, quando comparados ao grupo controle, que recebeu em seu leito apenas uma matriz de gelatina (Fig-02).

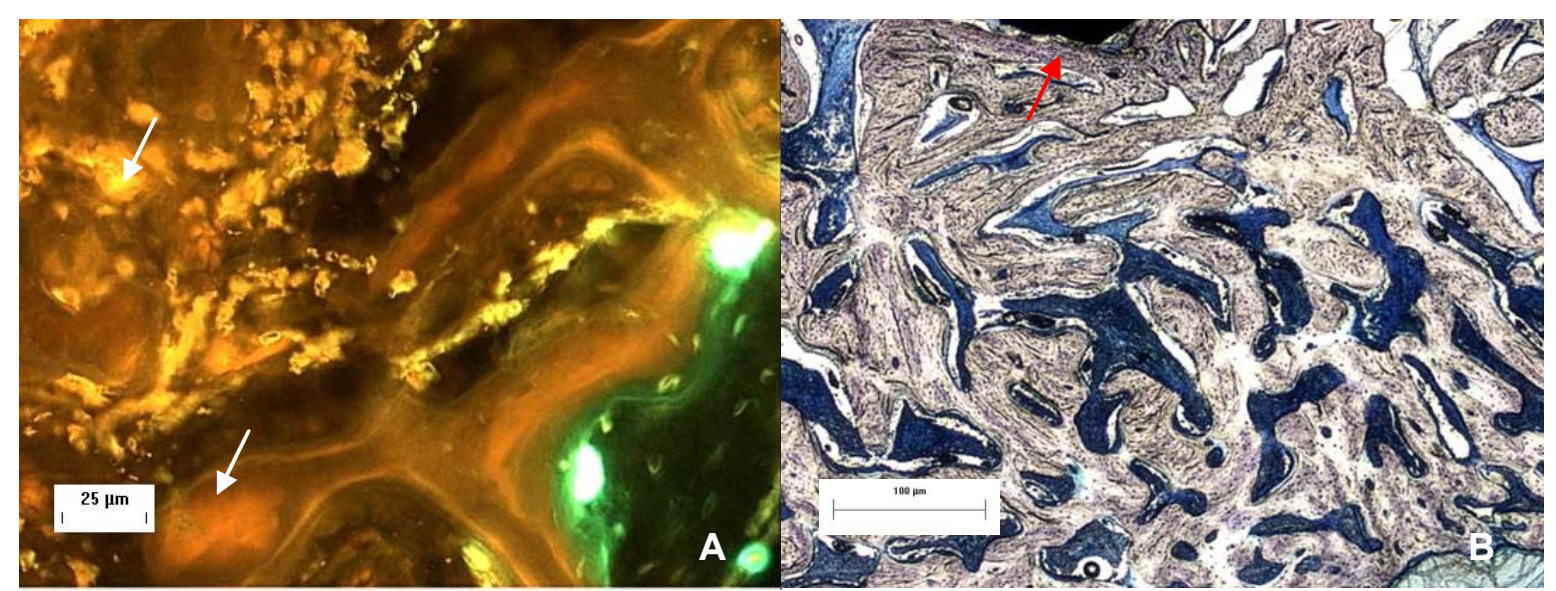

Fig. 02- As imagens acima representam experimento complementar realizado em tíbias de coelhos Nova Zelândia, utilizando o composto orgânico como enxerto ósseo. Neste experimento, a matriz aglutinante do Composto Orgânico foi alterada para colágeno hidrolizado. Nota-se em A uma expressiva marcação por tetraciclina (indicada pela seta). Este fármaco foi aplicado nas duas últimas semanas do experimento. Em B, observa-se também a intensa neoformação óssea na região periostal. Vê-se a região apical do implante (indicada pela seta), na qual há expressiva neoformação óssea em Azul de Toluidina.

Estes resultados iniciais motivaram o aprofundamento do conhecimento que se tinha até então e o questionamento de quais seriam os fatores determinantes para tais alterações dos resultados biológicos. Estes questionamentos levaram ao estudo dos eventos moleculares relacionados aos mecanismos de adaptação e estresse celular, onde uma endonuclease, o fator nuclear kappa-Beta (NF-kB), é considerada um sensor de estresse (HADDAD, 2002) cuja ativação induz a produção de citocinas pró-inflamatórias, a morte celular programada (apoptose), ou ainda a adaptação celular (LI e STARK, 2002; DOLCET et al., 2005; MOYNAGH, 2005; YAMAMOTO e GAYNOR, 2004; KUMAR et al., 2004; AGGARWAL, 2004; PERKINS, 2004; RAVI e BEDI, 2004), também descrita como um dos fatores responsáveis pela osteoporose (AHN e AGGARWALL, 2005).

Por tanto, o proposto inicial deste trabalho teve como método de avaliação a técnica de acrilização (por Techonovit 7200), isto é, a obtenção de lâminas de tecido ósseo calcificado que fossem passíveis de sofrer uma reação imunoistoquímica. $O$ desenvolvimento desta técnica traria uma série de vantagens ao estudo do tecido ósseo e principalmente à pesquisa na área de biomateriais, já que facilitaria a 
obtenção de informações acerca da relação tecido/biomaterial, possibilitando, assim, uma análise mais apurada dos efeitos dos biomateriais sobre o tecido ósseo.

Os desafios para conclusão desse trabalho foram muitos, desde a inexperiência e falta de conhecimento de seu autor em biologia molecular, até o desenvolvimento de uma técnica capaz de identificar proteínas em tecido ósseo não descalcificado. Mas o mesmo desconhecimento das dificuldades e certo grau de teimosia fizeram com que este trabalho chegasse a um bom termo, e espera-se realmente que as informações aqui contidas auxiliem os pesquisadores que trabalham nesta área.

\subsection{Sistema Lamelar do Osso}

As lamelas ósseas constituem a unidade anátomo-funcional do osso compacto, diferenciadas em quatro sistemas, que se tornam especialmente evidentes nas diáfises dos ossos longos. Estes sistemas lamelares se constituem em circunferencial externo e interno, sistemas de osteonas e intersticiais, segundo Gartner et al. (1999).

A maior parte do osso compacto é constituída de muitos canais ou sistemas osteônicos. Freqüentemente, o canal osteônico se bifurca ao longo de seu comprimento, formando os canais interosteônicos. Cada osteona se liga à sua contígua por meio de uma fina linha cementante, constituída, principalmente, de substância fundamental calcificada com uma pequena quantidade de fibras colágenas conhecidas por lamelas intersticiais. Os feixes de fibras colágenas são paralelos entre si, porém dispostos quase que perpendicularmente às lamelas adjacentes. Este arranjo se torna possível porque as fibras colágenas seguem um arranjo helicoidal ao redor dos canais osteônicos; porém, este arranjo não é congruente com as lamelas vizinhas, proporcionando assim um embricamento mecânico entre os sistemas lamelares, como descrevem Gartner et al. (1999).

Os canais osteônicos são revestidos por uma camada de osteoblastos e células osteoprogenitoras, abrigando também fibras nervosas e vasos sanguíneos. O diâmetro destes canais varia de 20 a $100 \mu \mathrm{m}$. À medida que as lamelas são formadas, o diâmetro dos canais se reduz e o sistema de osteonas aumenta (GARTNER et al., 1999). Em decorrência deste arranjo estrutural no osso cortical, ocorre uma deficiência de nutrição dos osteócitos. A nutrição que deriva dos canais 
maiores, osteônicos ou interosteônicos, deve necessariamente atingir as lacunas através dos canalículos, e estes atingem outras lacunas, sucessivamente, até que todos os nutrientes perfundam até os osteócitos mais periféricos. Esta perfusão de nutrientes se faz através da matriz extracelular, contida em uma estreita faixa, entre a matriz calcificada e o citoesqueleto dos osteócitos. A transmissão de sinais se faz por meio de junções comunicantes ou "gaps", contidos nas extremidades das extensões citoplasmáticas, entre os canalículos contíguos (GARTNER et al., 1999).

Este arranjo estrutural sugere uma intensa comunicação ente os osteócitos contidos nas lacunas (TURNER et al., 1994). Esta descrição foi idealizada pelo anatomista Julius Wolff no século XIX (BERTRAM e SWARTZ, 1991), que propôs que este tipo de arranjo poderia explicar o mecanismo de várias deformações anatômicas encontradas em ossos longos submetidos a diferentes cargas, isto é, um fêmur em indivíduos com a mesma altura, porém com pesos distintos, por exemplo, teria uma conformação diferente, em função destes achados. Wolff sugeriu a efetividade dos osteócitos na modelação e remodelação do tecido ósseo.

Atualmente, as pesquisas indicam que os osteócitos são verdadeiros mecanosensores que trabalham em conjunto, influenciando na remodelação do tecido ósseo, transformando este tecido em um verdadeiro sincício, onde a perfusão dos fluidos dentro dos sistemas de canais pode influenciar na dinâmica da remodelação e neoformação do tecido ósseo (MARK et al., 2000), indicando que os osteócitos têm uma participação efetiva na remodelação óssea (LANYON, 1993). Embora a remodelação e neoformação óssea estejam ligadas diretamente aos osteoblastos e osteoclastos, a biologia molecular demonstrou a ocorrência de inúmeras alterações na atividade e em níveis de expressão de alguns genes dentro dos osteócitos durante o processo de remodelação e reparação tecidual (NOMURA et al., 2000).

\subsection{Eventos Moleculares do Mecanismo de Estresse}

As mudanças na expressão e atividade gênicas decorrentes de um estímulo externo produzem internamente nas células uma reação em cadeia com a finalidade de adaptá-las a este novo ambiente. Esta adaptação a uma nova situação é transmitida a outras células através de sinais que alcançam o citoesqueleto, causando um influxo de cálcio para dentro destas células (HUNG et al., 1996). 
Subseqüente a esta entrada de cálcio ocorre uma mudança quase imediata na expressão dos níveis dos genes c-fos e cox-2 (LEAN et al., 1995; FORWOOD, 1996), o que promove o aumento dos níveis de AMPc (adenosyne monophosphateciclic), da produção de óxido nítrico $(\mathrm{ON})$ e de prostasciclinas $\left(\mathrm{PGI}_{2}\right)$ (PITSILLIDES et al., 1995; RAWLINSON et al., 1991). Tais ocorrências resultam no aumento da expressão de IGF-1 (Insulin-like-1 growth factor), fator de crescimento que é uma citocina. Todas as citocinas têm como caráter principal o fato de serem pleiotrópicas, ou seja, as mesmas desencadeiam efeitos diversos em células distintas. A IGF-1 estimula a síntese de colágeno tipo I, osteopontina (osteoponin - OPN) e osteocalcina (Osteocalcin - OCN) nas células osteogênicas, o que resulta em um incremento à formação de osso in vivo (NOMURA et al., 2000).

A osteopontina, também chamada de BSP-1 (bone sialoprotein-1), Eta-1 e 2ar, constitui o maior componente não fosforilado e não colágeno da matriz óssea, tendo uma importante função biológica nas ligações do cálcio aos seus domínios e na modificação da seqüência de aminoácidos - Gly-Arg-Gly-Asp-Ser (GRGDS) -, promovendo a ligação celular via integrinas (OLDBERG et al., 1986). Especula-se que estas ações são orquestradas por um único gene chamado SSRE (shear stress responsive element) ou elemento responsável pela divisão de stress (HSIEH et al., 1991).

Entretanto, a mecanotransdução de uma fratura e conseqüente formação de um calo ósseo ainda não foi bem esclarecida, porém artigos que descrevem o alongamento dos membros através de procedimentos de distração osteogênica (YASUI et al., 1997) fornecem algumas pistas das alterações moleculares e fisiológicas sofridas pelo tecido ósseo neste tipo de reparo.

Estas pesquisas descrevem a formação de uma camada cartilagínea externa ao calo ósseo (ossificação endocondral), enquanto na região endostal nota-se a ossificação membranosa. Somando-se a estas formas de ossificação, observa-se nestas regiões de distração osteogênica a direta formação do tecido ósseo iniciado por tecido cartilagíneo (YASUI et al., 1997), tipo de ossificação denominada de transcondróide por Roach (1992), raramente visto em uma ossificação fisiológica. A análise molecular e histológica deste tipo de ossificação evidenciou alterações na expressão no RNAm das células cartilagíneas do colágeno tipo II, durante os estágios iniciais da osteogênese. Posteriormente, notou-se a redução da expressão do colágeno tipo II no RNAm dos condrócitos, concomitante ao aumento na 
expressão do colágeno tipo I (YASUI et al., 1997). Um fato interessante neste experimento foi a identificação da expressão simultânea no RNAm dos condrócitos, da osteopontina, fosfatase alcalina e osteocalcina (SATO et al., 1998). Estes resultados sugerem que a diferenciação de condrócitos para condrócitos hipertróficos foi interrompida ou bloqueada, o que indica que estas células cartilagíneas podem se transdiferenciar em células da linhagem osteoblástica.

Entre os fatores que controlam a proliferação e a diferenciação dos condrócitos para osteoblastos, a expressão de uma BMP (Bone Morphogenetic Protein) ou proteína morfogenética óssea pode ter um papel central. O aumento dos níveis de expressão das BMPs-2 e 4 foi identificado em células osteogênicas e condrogênicas em regiões onde foram realizados defeitos ósseos (SATO et al., 1999). A abundante deposição de matriz óssea na região de distração osteogênica pode estar relacionada ao aumento da expressão de BMPs, especialmente a BMP-2 e a BMP-4, de acordo com Sato et al (1999).

Observa-se que o processo de reparação óssea necessita ser bem equilibrado e equacionado, de forma que as mudanças fisiológicas e as comunicações inter e intracelulares sejam diretamente interligadas para a perfeita formação de um novo tecido. Para tanto, a manutenção da integridade celular, sua função e uma melhor intercomunicação são de fundamental importância para que o processo de reparo possa se direcionar para a obtenção de um tecido ósseo organizado.

A complexidade dos eventos moleculares responsáveis pelo reparo de uma fratura e subseqüente formação do calo ósseo, discutidos anteriormente, está diretamente relacionada a outro processo, tão complexo e ainda não totalmente conhecido, chamado processo inflamatório.

\subsection{Inflamação}

O processo de inflamação - a flogose (do latim inflamare e do grego phlogos, que significam pegar fogo) - é caracterizado por uma reação dos tecidos vascularizados a um agente agressor. Esta reação pode ser dividida em duas fases, inflamação e reparo, que estão intimamente associadas, constituindo um processo único. Tal processo tem como finalidade destruir, diluir ou isolar os agentes lesivos, bem como as células do tecido que possam ter sido destruídas durante a 
inflamação. Por outro lado, a resposta inflamatória desencadeia uma série complexa de eventos que, tanto quanto possível, cicatriza e reconstitui o tecido lesado. $O$ reparo começa durante a fase ativa da inflamação, porém atinge o seu término após a influência lesiva ter sido neutralizada (ROBBINS, 1991). As células destruídas, assim como os tecidos subjacentes, são substituídos por células vivas. Isto ocorre pela proliferação de células parenquimatosas nativas, embora mais freqüentemente pelo preenchimento do defeito com fibras colágenas, que formam um tecido cicatricial (ROBBINS, 1991).

O processo infamatório é um fenômeno essencialmente dinâmico, razão pela qual seu aspecto morfológico se modifica, vinculando-se a variados tipos de agente agressor. Assim, tal processo estabelece mecanismos de defesa para situações distintas. Essencialmente, observam-se dois tipos distintos deste processo: a inflamação aguda e a crônica. Na primeira, o agente causal é destruído ou inativado, permitindo a cura ou reparo do tecido lesado. Na inflamação crônica, o agente agressor é de difícil eliminação. Isto possivelmente ocorre por uma ação repetitiva por parte do agente agressor ou por uma indução a uma resposta imunológica de seus antígenos. Nestas circunstâncias, a resposta inflamatória persiste em razão da geração contínua de mediadores que estimulam a exsudação celular. Neste caso, o tempo de duração do processo inflamatório é muito variável (BOGLIOLO et al., 2000).

A resposta a um agressor é estabelecida pela liberação de mediadores que induzem a modificações na micro-circulação local e estimulam a migração de fagócitos para o interstício e/ou para a região da lesão. Entre os vários mediadores químicos, encontram-se as citocinas, que desempenham uma importante função na resposta inflamatória local e sistêmica.

As citocinas são peptídeos que regulam e determinam a natureza da resposta imunológica, além de atuarem sobre a resposta inespecífica dos tecidos frente a variadas agressões. São sintetizadas por células do sistema imunológico (linfócitos, macrófagos e células dendríticas), por células acessórias deste sistema (eosinófilos, basófilos e mastócitos), por células endoteliais e mesenquimais e por várias outras células, desde que devidamente estimuladas (BOGLIOLO et al., 2000). Estes peptídeos foram inicialmente denominados como interleucinas, pois se acreditava que os mesmos eram substâncias produzidas por leucócitos. Como atualmente sabe-se que as células não leucocitárias podem produzir e ser alvo das 
interleucinas, o termo citocina é mais apropriado para se referir a esse grupo de substâncias (BOGLIOLO et al., 2000).

Os vários mediadores inflamatórios, incluindo as citocinas, normalmente atuam no sentido de restringir as conseqüências e a extensão do dano tecidual, induzindo somente os sinais locais, ou seja, dor, rubor e calor (BOGLIOLO et al., 2000). Dependendo da persistência e/ou intensidade da lesão, as citocinas podem difundir-se e mediar sinais e sintomas sistêmicos como febre, aumento da produção de proteínas da fase aguda, leucocitose, ativação do sistema complementar, aumento da produção de glicocorticóides e alterações metabólicas e das concentrações plasmáticas de íons metálicos como ferro, cobre e zinco. Esta resposta sistêmica é denominada resposta de fase aguda - RFA (STADNYK e GAULDIE, 1991).

As citocinas têm como características principais a possibilidade de serem produzidas por estímulo gerado diretamente por microrganismos invasores, fazendo parte dos mecanismos inespecíficos de defesa; o fato de serem secretadas por um período curto e em quantidades limitadas; a grande redundância em relação a suas fontes e efeitos, pois uma mesma citocina pode ser produzida por células distintas, assim como citocinas diferentes podem produzir o mesmo efeito; o fato de muitas citocinas terem efeito pleiotrófico, ou seja, efeito em células distintas; a influência que uma citocina freqüentemente tem na síntese de outra, inibindo-a ou estimulando-a. Além destas características, deve-se considerar, ainda, que todas as citocinas agem sobre receptores celulares, não sendo raro que o mesmo receptor possa se ligar a diferentes citocinas, embora com afinidades diferentes. Os resultados gerados normalmente após efeitos das citocinas manifestam-se como uma indução gênica, com síntese de RNAm, e seus efeitos são mediados não imediatos, manifestando-se após a ligação com o receptor (BOGLIOLO et al., 2000).

A modulação da reação inflamatória envolve uma complexa interação de mediadores sinérgicos e/ou antagônicos em várias fases do processo. Para tanto, se faz necessário compreender que, enquanto mediadores pró-inflamatórios diminuem em quantidade, os efeitos dos mediadores antiinflamatórios tornam-se mais evidentes, mesmo que não haja aumento da concentração destes na área inflamada. Por outro lado, alguns agentes inflamatórios têm espectro de ação mais amplo, por inibirem mecanismos de transdução e geração de mensageiros, utilizados por mediadores diferentes. As citocinas liberadas no foco inflamatório, 
especialmente IL-1, TNFa e IL-6, induzem a chamada reação de fase aguda, com produção e liberação de proteínas de ação antienzimática, indutores de agregação e diferenciação celular e de hormônios que interferem na inflamação (BOGLIOLO et al., 2000).

A cicatrização de um tecido lesado muitas vezes não coincide com a reparação anatômica, implicando uma perda tecidual ou a substituição do mesmo por um tecido fibrótico não funcional. Os fatores que modulam a proliferação celular, apoptose e necrose a partir do processo inflamatório inicial são cruciais no reparo do tecido danificado. Portanto, a cicatrização do tecido lesado é definida nos estágios iniciais do processo de reparo (KHODR e KHALIL, 2001).

\subsection{Apoptose e Necrose - Informações Gerais}

Oriunda da língua grega, a palavra "apoptose" (que significa folhas caindo das árvores ou pétalas caindo das flores) passou a ser empregada em biologia celular por Kerr et al (1972). Estes mesmos autores realizaram uma importante revisão sobre o tema, estudando o aspecto morfológico da morte celular em células isoladas e em tecidos, a partir da qual verificaram a existência de dois tipos distintos de morte celular: a apoptose e a necrose, que seguiam padrões distintos de comportamento.

Normalmente, a apoptose se caracterizava por uma morte limpa (sem a presença do processo inflamatório), isto é, em tecidos em desenvolvimento ou em adaptação, como ao longo da embriogênese ou na reabsorção do tecido mamário após a lactação. Este processo apoptótico é caracterizado por sua organização, tendo início em períodos pré-determinados com evolução bem conhecida e seu término característico. O processo é definido também por um importante mecanismo de controle fisiológico dos processos degenerativos sem a presença dos fatores deletérios do processo inflamatório. As células que sofrem apoptose tendem a apresentar um volume reduzido, mantendo a integridade das organelas, porém normalmente se destacam das células vizinhas (processo chamado Zeiose). As maiores alterações morfológicas ocorrem no núcleo, com a cromatina intensamente enovelada, fragmentando-se quando fagocitada por células vizinhas ou por macrófagos.

Em contraposição, o tecido que foi submetido a algum trauma severo como alta temperatura, pH extremo ou infecções virais, também está sujeito a apresentar 
um padrão de morte celular característico chamado necrose. Estas células associadas a padrões patológicos apresentam volume aumentado, contorno nuclear ausente ou pouco definido, mitocôndrias e demais organelas intumescidas ou rompidas, o que inviabiliza a vida das mesmas.

Os aspectos morfológicos da apoptose e necrose foram apresentados por Wyllie et al (1980), quando descreveram as etapas pelas quais as células passam durante os processos apoptótico e necrótico.

$\mathrm{Na}$ apoptose, as células evidenciam como primeiras alterações perceptíveis a agregação da cromatina em grandes corpos granulares que se ligam à membrana nuclear interna. O contorno nuclear apresenta-se anormalmente convoluto (sinuoso), o núcleo torna-se aumentado, com grânulos pronunciados e dispersos, sendo que também surgem grânulos finos no centro do núcleo, porém os poros nucleares permanecem inalterados. Ao mesmo tempo, o citoplasma condensa-se, ocorrendo alterações da superfície celular como a perda das microvilosidades e o surgimento de protuberâncias na superfície celular. Nos tecidos, as células apoptóticas se separam das vizinhas, e em seguida, ocorre um aumento na condensação do citoplasma, o que promove um aumento na densidade das organelas. Porém, com a manutenção da integridade destas, surgem no citoplasma vacúolos translúcidos, enquanto no citoesqueleto as alterações se tornam cada vez mais evidentes com o surgimento de bolhas. Neste momento, ocorre a fragmentação do núcleo, com a organização da cromatina em "lua crescente", lateralmente localizada em cada fragmento do núcleo, com uma intensa coloração basófila. Alguns destes fragmentos nucleares são delimitados pela dupla membrana nuclear e em outros há ausência desta membrana. Finalmente, ocorre o destacamento das protuberâncias ou bolhas formadas no citoesqueleto, chamados de corpos apoptóticos, os quais podem conter porções celulares. Esses fragmentos são então freqüentemente fagocitados por células vizinhas ou células fagocitárias.

As alterações morfológicas que ocorrem nas células ao longo da necrose são: agregação parcial da cromatina, dilatação do retículo endoplasmático e das mitocôndrias e dispersão dos ribossomos. Ocorre, então, a ruptura das membranas nucleares e das organelas citoplasmáticas, com aparecimento de material floculado na mitocôndria e dissolução de ribossomos e lisossomos. À medida que o núcleo aumenta em diâmetro, a cromatina torna-se dispersa e deixa de ser vista. Toda a basofilia é então perdida, assim como passam a ser indistingüíveis os limites entre 
as organelas, gerando as chamadas células fantasmas (ghost cells). Após o rompimento celular, o tecido passa a desenvolver uma reação inflamatória.

Estes dois tipos de morte celular são mediados pelo estresse oxidativo, provocado principalmente por espécies reativas de oxigênio (ROS). Estes agentes oxidantes podem induzir um ou outro tipo de morte celular, dependendo da intensidade da liberação e formação destes radicais na região lesada (RISSMAN et al., 2004).

\subsection{Sistema Oxidante}

Há cerca de 15 anos, foi demonstrada a presença de espécies reativas de oxigênio (ROS) contendo um número ímpar de elétrons altamente reativos: $\mathrm{O}_{2}$ (ânion superóxido), $\mathrm{H}_{2} \mathrm{O}_{2}$ (peróxido de hidrogênio) e $\mathrm{OH}$ (radical hidroxila) (DEL MAESTRO, 1980; GRANGER et al., 1981). Este oxigênio molecular está presente em todas as células que têm este elemento como último aceptor de elétrons em sua cadeia respiratória (HADDAD, 2002). A formação de ROS ocorre de forma contínua na célula que apresenta mecanismos para inativá-la. Há sistemas associados ao transporte e troca de oxigênio que produzem radicais livres como subproduto da atividade metabólica normal. Muitos destes sistemas possuem íons metálicos como o ferro, que ao passar do estado ferroso $\left(\mathrm{Fe}^{++}\right)$ao férrico $\left(\mathrm{Fe}^{+++}\right)$, isto é, de um estado redutor para outro oxidado, podem catalisar a formação de radicais livres.

Entre as fontes mais importantes de geração de ROS estão as hemoglobinas, o sistema de oxidação conhecido como citocromo P-450, localizado no retículo endoplasmático rugoso (RER) e a cadeia respiratória contida nas mitocôndrias. A maior parte do oxigênio consumido pelas células vai para a fosforilação oxidativa $\left(\mathrm{O} \rightarrow \mathrm{H}_{2} \mathrm{O}\right)$; porém, muitas enzimas que funcionam em várias vias metabólicas; geralmente usando íons metálicos como co-fator, transferem elétrons para $\mathrm{o} \mathrm{O}_{2}$ ou para a NAD (Nicotinamide Adenine Dinucleotide). No fígado, a ação das enzimas oxidases pode chegar a 1/3 do consumo de oxigênio do tecido.

A redução do $\mathrm{O}_{2}$ a $2 \mathrm{H}_{2} \mathrm{O}$ por inserção direta de dois pares de elétrons é um processo energeticamente difícil, devido à peculiaridade dos elétrons nas órbitas externas. Se não fosse por isto, a coexistência de oxigênio molecular com organismos vivos seria impossível. Esta dificuldade é diminuída pela adição sucessiva de elétrons um a um representada a seguir: 
A adição do primeiro elétron produz o íon superóxido.

$$
\mathrm{O}_{2}+\mathrm{e}^{-} \rightarrow \mathrm{O}_{2}^{-}
$$

Este $\mathrm{O}_{2}{ }^{-}$é facilmente protonado (efeito de ligar próton a um substrato) a $\mathrm{HO}$ (radical hidroxila), que reage com outro radical igual e se dismuta (oxidoredução) em $\mathrm{H}_{2} \mathrm{O}_{2}$ e $\mathrm{O}_{2}$.

$$
\begin{gathered}
\mathrm{O}_{2}^{-}+\mathrm{H}^{+} \leftrightarrow \mathrm{HO}_{2}^{-} \\
\mathrm{HO}_{2}^{-}+\mathrm{O}_{2-}^{-}+\mathrm{H}+\rightarrow \mathrm{H}_{2} \mathrm{O}_{2}+\mathrm{O}_{2} .
\end{gathered}
$$

Portanto, qualquer sistema que produza superóxido $\left(\mathrm{O}_{2}{ }^{\circ}\right)$, logo conterá peróxido de hidrogênio $\left(\mathrm{H}_{2} \mathrm{O}_{2}\right)$. Além disso, na presença de íons ferro, provoca-se duas reações importantes, que ocorrem entre o íon superóxido e o peróxido de hidrogênio.

$$
\begin{gathered}
\mathrm{O}_{2}^{-}+\mathrm{Fe}^{+++} \rightarrow \mathrm{Fe}^{++}+\mathrm{O}_{2} \\
\mathrm{H}_{2} \mathrm{O}_{2}+\mathrm{Fe}^{++} \rightarrow \mathrm{Fe}^{+++}+\mathrm{HO}^{-}+\mathrm{HO}^{\circ}
\end{gathered}
$$

Este processo é chamado de reação de Fenton. É através desta reação que são gerados os radicais hidroxila $\left(\mathrm{HO}^{\circ}\right)$ que, dentre os vários radicais livres, são considerados como a espécie mais reativa. Na outra reação denominada de Haber Weiss, omitindo-se a participação do ferro, que funciona como catalisador, atuando como aceptor e doador de elétrons, tem-se:

$$
\mathrm{H}_{2} \mathrm{O}_{2}+\mathrm{O}_{2}^{-} \rightarrow \mathrm{O}_{2}+\mathrm{HO}^{-}+\mathrm{HO}^{\circ}
$$

Em resumo, a produção inicial do íon superóxido resultará, através destes intermediários, na produção do radical livre hidroxila.

As reações mediadas pelas espécies reativas de oxigênio têm natureza de propagação, como visto anteriormente. Tais reações em cadeia se iniciam pela presença de espécies reativas de oxigênio (ROS), propagando-se de forma radicalar (expressão bioquímica, com o significado de reação em cadeia). Este processo cessará quando ocorrer uma quebra e/ou bloqueio da geração destes radicais livres 
por intermédio de agentes antioxidantes, impedindo ou bloqueando a formação de mais radicais, quebrando a reação em cadeia (HALLIWELL e GUTTERIDGE, 1989).

A produção descontrolada dos radicais livres pode provocar inúmeras patologias como: arteriosclerose, inflamações crônicas, doenças degenerativas e câncer. Muitos são os alvos destes radicais livres, como, por exemplo, as proteínas, os lipídeos e os ácidos nucléicos. Os primeiros podem se desnaturar ou simplesmente perder a sua função. Isto pode ocorrer, pois o DNA danificado pode produzir falhas na transcrição, provocando uma mutação ou, conforme a intensidade da agressão, inviabilizar a vida da célula, o que finalizaria em morte por apoptose ou por necrose. $\mathrm{O}$ ataque dos radicais livres aos lipídios tem uma natureza propagante, levando a uma degeneração da membrana celular, chamada de peroxidação lipídica (POMPÉIA, 2003).

Todos componentes celulares são suscetíveis à ação das ROS; porém, a membrana é um dos mais atingidos em decorrência da peroxidação lipídica, que acarreta alterações na estrutura e na permeabilidade das membranas celulares (MELLO FILHO at al, 1983). Conseqüentemente, há perda da seletividade na troca iônica e liberação do conteúdo de organelas, como as enzimas hidrolíticas dos lisossomas; e formação de produtos citotóxicos (malonaldeído), culminando na morte celular (HERSHKO, 1989). A lipoperoxidação também pode estar associada aos mecanismos de envelhecimento, câncer e à exacerbação da toxicidade de xenobióticos (SHAN, 1990). Assim como na formação das ROS, nem sempre os processos de lipoperoxidação são prejudiciais, pois seus produtos são importantes na reação em cascata a partir do ácido aracdônico na formação de prostaglandinas e, portanto, na resposta inflamatória (ROSS e MOLDEUS, 1991).

A lipoperoxidação é uma reação em cadeia representada pelas etapas de iniciação, propagação e terminação. Estas etapas são apresentadas nas reações seguintes, onde L representa o lipídio (GARDÈS-ALBERT, 1991).

Tabela 1 - Peroxidação Lipídica

\begin{tabular}{lllr}
\hline $\mathrm{LH}^{+} \mathrm{OH}^{\circ}\left(\right.$ ou LO $\left.^{\circ}\right)$ & $\rightarrow$ & $\mathrm{L}^{\circ}+\mathrm{H}_{2} \mathrm{O}$ ou $\mathrm{LOH}$ & Iniciação \\
\hline $\mathrm{L}^{\circ}+\mathrm{O}$ & $\rightarrow$ & $\mathrm{LOO}^{\circ}$ & Propagação \\
\hline $\mathrm{LH}+\mathrm{LOO}^{\circ}$ & $\rightarrow$ & $\mathrm{L}^{\circ}+\mathrm{LOOH}$ & Propagação \\
\hline $\mathrm{LOO}^{\circ}+\mathrm{L}^{\circ}$ & $\rightarrow$ & $\mathrm{LOOL}$ & Terminação \\
\hline $\mathrm{LOO}^{\circ}+\mathrm{LOO}^{\circ}$ & $\rightarrow$ & $\mathrm{LOOL}+\mathrm{O}_{2}$ & Terminação \\
\hline
\end{tabular}


As reações acima têm inicio com o seqüestro do hidrogênio do ácido graxo polinsaturado $(\mathrm{LH})$ da membrana celular. Tal seqüestro pode ser realizado pelo $\mathrm{OH}$ ou pelo radical LO' (radical alcoxila), com conseqüente formação de $\mathrm{L}^{\circ}$ (radical lipídico). Na primeira equação de propagação, o $\mathrm{L}^{*}$ reage rapidamente com $\circ \mathrm{O}_{2}$, resultando em LOO' (radical peroxila), que, por sua vez, seqüestra novo hidrogênio do ácido graxo polinsaturado, formando novamente o $L^{*}$ na segunda equação de propagação. $O$ término da lipoperoxidação ocorre quando os radicais ( $\mathrm{L}^{*}$ e $\mathrm{LOO}^{\circ}$ ) produzidos nas etapas anteriores se propagam até a auto-destruição.

A lipoperoxidação pode ser catalisada por íons ferro por conversão de hidroperóxidos lipídicos (LOOH) em radicais altamente reativos \{alcoxila (LO*) e peroxila ( $\left.\left(\mathrm{LO}^{\circ}\right)\right\}$, que, por sua vez, iniciam novas cadeias de reações, denominadas ramificações. Estas reações, que podem ser rápidas ou lentas, dependem da valência do ferro (BORG e SCHAICH, 1988).

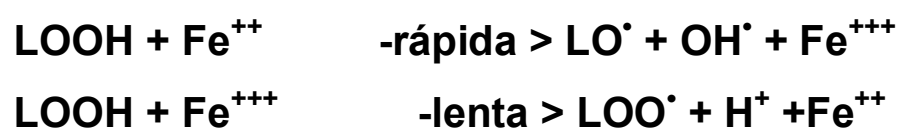

Os radicais hidroxila $\left(\mathrm{OH}^{*}\right)$ são freqüentemente reconhecidos como a espécie iniciadora e a mais importante da lipoperoxidação (GUTTERIDGE, 1988). Entretanto, estudos indicam que o ferro também desempenha papel determinante na iniciação deste processo, sendo necessária na relação equimolar $\mathrm{Fe}^{+++} / \mathrm{Fe}^{++}$no meio, para que ocorra a lipoperoxidação (MINOTTI e AUST, 1987; HORTON et al., 1989).

As alterações em proteínas ocorrem geralmente pelo produto da peroxidação lipídica (malonaldeído), atingindo principalmente os grupos sulfidrilas $(-\mathrm{SH})$, formando grupos disulfeto (S-S). Os aminoácidos mais sensíveis são a cisteína, metionina, histidina e lisina. Com isto, podem ocorrer ligações cruzadas entre as moléculas vizinhas, alterações de propriedades de moléculas de membrana e, principalmente, inativação de enzimas. Este grupo, sulfidrila, é critico para a ação das várias enzimas, pois faz parte do sítio ativo. As alterações nos ácidos nucléicos atingem principalmente as bases nitrogenadas (púricas e pirimidínicas). Estas alterações também são efetuadas por ligações cruzadas entre aminoácidos, levando a uma alteração no DNA, o que gera posteriormente alterações que podem levar ao desenvolvimento de uma lesão maligna (SEN, 1998). 


\subsection{Proteção Anti-Oxidativa}

Paradoxalmente, o oxigênio carrega a morte aos organismos aeróbicos. Para combater os danos causados pelas espécies reativas de oxigênio (ROS), os organismos aeróbicos desenvolveram uma série de defesas tanto intra como extracelulares. O sistema intracelular é composto por uma série de enzimas que agem como agentes antioxidantes. Deste mecanismo fazem parte a superoxidodismutase (SOD), catalase, glutationa e glutadiona peroxidase. A superoxidodismutase (SOD) é uma enzima ubíqua, contida em todos tecidos aeróbicos, necessitando do íon ferro para sua atividade na matriz extracelular, do cobre e zinco no citoplasma, e do manganês nas mitocôndrias. Esta dependência do íon ferro é importante para os procariotos, sendo que a atividade cinética antioxidativa da SOD é muito eficiente, convertendo os RL, em uma velocidade $10^{10}$ vezes mais rápida que sua gênese, em pH fisiológico (IGNATOWICZ et al., 1994). Seu mecanismo de ação, sua atividade e sua estrutura são bem conhecidos (LEVIEUX et al., 1991; LIPECKA, 1989). Os radicais peróxido formados na reação de oxidação são transferidos através da enzima SOD-catalase para as catalases ou para as glutationas peroxidades (GPx) e em seguida convertidos em elementos não danosos como água e oxigênio, que serão utilizados posteriormente.

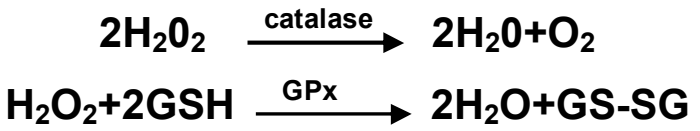

A catalase é uma hemoproteína composta por quatro subunidades monoméricas essencialmente localizadas dentro das células, nos peroxissomos, cuja ação decompõe o peróxido $\left(\mathrm{H}_{2} \mathrm{O}_{2}\right)$ em água e moléculas de oxigênio. Também envolvida no sistema Redox, a glutationa é considerada scavenger para os radicais de hidrogênio e para o oxigênio singlet $\left(\mathrm{O}^{\circ}\right)$. Esta enzima também é capaz de reativar outras enzimas que sofreram danos por uma exposição a altas concentrações de oxigênio (MAELLARO et al., 1990; MUNDAY et al., 1989; ROSS, 1988; SHAN, 1990).

Os antioxidantes extracelulares têm ações mais variadas, quebrando ou bloqueando a geração dos radicais livres. Com isto, conseguem diminuir os efeitos deletérios da reação inflamatória. Um destes agentes antioxidantes é a vitamina $\mathrm{E}$ 
ou a-tocoferol, que freia a geração dos radicais livres e limpa os átomos de oxigênio singlet $\left(\mathrm{O}^{\circ}\right)$. Por sua composição lipossolúvel, este agente tem um importante papel na proteção da membrana celular, impedindo a propagação da peroxidação lipídica (TAKENAKA et al., 1991; THOMAS et al., 1990). O licopeno e a-caroteno, proveniente da pró-vitamína-A, também fazem parte desta classe de antioxidantes e têm grande importância na decomposição dos átomos de oxigênio singlet $\left(\mathrm{O}^{\circ}\right)$ e na proteção contra a peroxidação lipídica, sendo utilizados também na prevenção de cânceres (MACHLIN et al., 1987). As proteínas do plasma também têm atividade antioxidante, baseando-se em vários mecanismos de ação. É descrito que a albumina humana captura $50 \%$ dos radicais peróxidos circundantes, em função do grupo sulfidrila (WAYNER et al., 1897), ligando-se ao cobre extracelular circundante e inibindo o grupo peróxido $\left(\mathrm{HO}^{\circ}\right)$, impedindo a formação de peróxido de hidrogênio (HALLIWELL et al., 1989), formando um complexo chamado de caerulosplasmina, capaz de reagir com os superóxidos circundantes, conforme a reação descrita abaixo:

\section{Caeruloplasmina- $\mathrm{Cu}^{2+}+\mathrm{O}_{2}^{--} \longrightarrow$ Caeruloplasmina-Cu${ }^{+}+\mathrm{O}_{2}$}

A capacidade de quelar íons metálicos em transição faz deste elemento um importante agente de proteção contra a peroxidação lipídica, sendo considerado um importante mecanismo de proteção antioxidante (IGNATOWICZ et al., 1994).

Os radicais livres podem estar também envolvidos no processo de envelhecimento, hipótese esta proposta por Harman, em 1956. Possivelmente, no decorrer da vida, ocorre um aumento do desequilíbrio entre a produção de radicais livres e a proteção antioxidante, conduzindo a um acúmulo de radicais com subseqüente lesão aos tecidos (STARKE-REED et al., 1989). Idosos acometidos por doenças agudas ou crônicas apresentam níveis de antioxidantes naturais reduzidos, o que resulta em maiores danos aos tecidos, provocados pela peroxidação lipídica (HARMAN 1992 e 1993). Isto não é uma evidência conclusiva de que o envelhecimento esteja diretamente ligado à contínua redução da proteção antioxidante, o que gera danos ao DNA e conseqüente morte dos tecidos; mas é indiscutível que a peroxidação lipídica é mais evidente em pessoas idosas. Entretanto, até este momento, um tratamento com agentes antioxidativos não pode 
ser criticamente analisado e, desta forma, não se pode afirmar a eficiência deste tratamento em pacientes idosos (HARMAN, 1992).

Atualmente, estes conhecimentos básicos estão sendo direcionados para a clínica, sendo desenvolvidas terapias e fármacos capazes de reduzir a peroxidação lipídica e o estresse oxidativo. Os estudos estão mais concentrados na terapia do câncer, como agente desintoxicante após quimioterapia, nas escleroses, terapias voltadas à prevenção de acidentes cardiovasculares e processos neurodegenerativos (ORÁKOVÁ e STOLC, 1998; HAYES e MACHON, 2001).

\subsection{Oxidação/Redução (Redox)}

Estado redox é um termo extensamente utilizado quando se trata de sistemas biológicos, sendo empregado para a descrição de fenômenos intracelulares de oxidação e redução, ou simplesmente estado redox. Os mecanismos responsáveis por regular e manter o estado de equilíbrio redox não são completamente conhecidos. Na classificação das reações químicas, os termos oxidação e redução compreendem um amplo e diversificado conjunto de processos.

Por definição, oxidação é o processo químico em que uma substância perde elétrons. O mecanismo inverso, a redução, consiste no ganho de elétron por um átomo, que o incorpora em sua estrutura. Tais processos são simultâneos à reação resultante, que é chamada de oxi-redução ou simplesmente redox. Assim sendo, uma substância redutora cede alguns de seus elétrons e, conseqüentemente, se oxida; enquanto a outra, oxidada, retém estes elétrons e sofre um processo de redução. Ainda que os termos oxidação e redução se apliquem às moléculas em seu conjunto, apenas um dos átomos integrantes da molécula é que se reduz ou se oxida (HADAAD, 2002).

A relação oxidação-redução, ou estado redox, constitui-se em fator significativo para a manutenção da homeostase celular ou a adaptação das mesmas em decorrência de alterações extracelulares. Este equilíbrio é regulado por meio de grupos tióis ${ }^{\bullet}$ livres (glutationa e tioredoxina), permitindo que as funções celulares essenciais sejam realizadas e o equilíbrio celular seja mantido. A ruptura ou quebra deste equilíbrio por intermédio de fatores intra ou extracelulares implica uma resposta intracelular, resultando muitas vezes na expressão de genes. O mecanismo pelo qual ocorre a transcrição de genes específicos para a adaptação celular é

• Designação genérica de substâncias que contêm o grupo-SH ligado a carbono saturado 
regulado pelo estado redox em células eucarióticas, sendo este bastante complexo. Para ARRIGO et al. (1999), os fatores de transcrição, sensíveis ao estado redox, representam um importante papel no processo de reparo.

Biologicamente, o processo redox adquiriu no momento uma nova dimensão, quando nos voltamos às espécies reativas de oxigênio. Nos seres vivos cujo metabolismo utiliza o oxigênio como último aceptor de elétrons, isto é, utiliza respiração aeróbica para a produção de energia, invariavelmente é produzida uma pequena quantidade de ROS, que de alguma forma influencia cada órgão e cada célula destes indivíduos (HADDAD, 2002). A ruptura do equilíbrio redox pode provocar um aumento exacerbado da produção de ROS, e conforme a proteção antioxidante do tecido ou da célula, pode ocorrer o chamado estresse oxidativo. As causas deste estresse oxidativo podem ser divididas em duas classes: a interna (inflamação, reações auto-imunes, problemas metabólicos e isquemia) e a externa (organismos microbiológicos, radiação eletromagnética ou mecânica, ação térmica ou química). Com a instalação deste estresse no metabolismo celular, pode ocorrer a geração do dano oxidativo, que é definido como a falta de habilidade do organismo ou célula para se defender contra as espécies reativas de oxigênio e/ou nitrogênio. Portanto, só existirá dano oxidativo se as defesas antioxidantes do organismo falharem.

\subsection{Sensor de oxigênio}

Como as células percebem o oxigênio e respondem a ele? Há implicações fisiológicas e fisiopatológicas (PEERS e KEMP, 2001; WENGER, 2000; ACKER 1994). Os organismos aeróbicos desenvolveram um elaborado mecanismo adaptativo, que mantém o oxigênio em equilíbrio, mantendo assim a homeostase celular e tecidual. Nos mamíferos, este complexo mecanismo permitiu que a aquisição e a distribuição do oxigênio guardasse a função de substrato para a fosforilação oxidativa, proporcionando a produção de Adenosina Trifosfato (ATP) (WENGER, 2000; FEHRENBACH, 2001). Este mecanismo fez com que o oxigênio molecular ocupasse um papel essencial em muitos processos metabólicos (PEERS e KEMP, 2001; WENGER, 2000; ACKER, 1994; FEHRENBACH, 2001; CRAPO e

BARRY, 1980), promovendo o desenvolvimento de sinalizações que regulam o 
metabolismo energético, o crescimento e a diferenciação celular (PEERS e KEMP, 2001; WENGER, 2000; CRAPO e BARRY, 1980; HADDAD e LAND, 2000).

Apesar desta função essencial a todos os organismos superiores, os mecanismos de percepção dos níveis de oxigênio molecular e a conversão em informações ainda permanecem obscuros (HADDAD, 2000; DESAI e CARDOSO, 2002; ARRIGO, 1999; SEN e PACKER, 1996; SEN, 2000; HADDAD e LAND, 2000; HADDAD et al., 2001); porém, estudos têm demonstrado que esta molécula $\mathrm{O}_{2}$ está de fato envolvida em sinalização biológica (PEERS e KEMP, 2001; CRAPO et al., 1980; ACARREGUI et al., 1995). O termo "regulação oxidativa" foi proposto para indicar a efetiva modulação do processo redox em proteínas na regulação da função celular. As reações de óxido-redução de biomoléculas, principalmente proteínas, eram consideradas como estresse oxidativo. Atualmente, são consideradas como sinalizações, que contêm informações biológicas necessárias para a manutenção da homeostase celular (HADDAD, 2004).

Dessa forma, como se pode identificar um biomarcador ou um biosensor, capaz de identificar o processo oxidoredutor intracelular? Algumas propostas têm sido formuladas nos últimos anos e algumas delas serão evidenciadas em seguida.

Estudos com EPO (erythropoietin) ou eritropoitina (PEERS e KEMP, 2001; WENGER, 2000; ACKER, 1994; FEHRENBACH, 2001; CRAPO e BARRY, 1980; ROONEY et al., 1994; KLINGS e FARBER, 2001; KEANE e STRIETER, 2002), uma glicoproteína necessária para a diferenciação e proliferação de eritrócitos, demonstraram que a mesma está aumentada em tecidos que sofreram hipóxia (DESAI e CARDOSO, 2002; ACARREGUI et al., 1995). Além disto, existe a indução da expressão da EPO por metais de transição (elementos que formam, ao menos, um íon que tenha uma orbital $d$ incompleta), como cobalto $(\mathrm{Co} 2+)$ e níquel $(\mathrm{Ni} 2+)$, suportando a hipótese de que o sensor de oxigênio pode induzir a produção de glicoproteínas (ROONEY et al., 1994; HADDAD, 2001). Autores sugerem o monóxido de carbono ( $\mathrm{CO}$ ) como um candidato a sensor do oxigênio, já que pode não covalentemente ligar-se ao átomo de ferro $\left(\mathrm{Fe}^{2+}\right)$ nos grupos heme no interior das hemoglobinas, mioglobinas, citocromos e outras heme-proteínas (ALDER, 1999; RICHALET, 1997), da mesma forma que o oxigênio estruturalmente faz suas ligações com estes grupos heme. Isto sugere que, em determinadas situações, o CO pode se ligar ao grupo heme em uma conformação oxi, podendo, da mesma maneira 
que o oxigênio, alterar a função destas proteínas (PEERS e KEMP, 2001; WENGER, 2000; ACKER, 1994; FEHRENBACH, 2001; CRAPO E BARRY, 1980; KLINGS e FARBER, 2001; KEANE e STRIETER, 2002; CHEN et al., 1998; NESIN e CUNNINGHAM-RUNDLES, 2000; SAUGSTAD, 1985; FU et al., 1997; HADDAD, 2000; HADDAD et al., 2001; HADDAD et al., 2001).

FANDREY et al. (1990) inequivocamente sugeriram que o sensor de oxigênio pode estar envolvido com microssomas, combinando com as funções das enzimas oxidases. Isto foi proposto porque a eritropoitina envolve uma interação com o citocromo P450 e uma enzima chamada citocromo P450 redutase, permitindo, assim, a conversão do oxigênio molecular para oxigênio singlet $\left(\mathrm{O}_{2}^{-}\right)$e $\mathrm{H}_{2} \mathrm{O}_{2}$ (ROUVEIX, 1997; BORASCHI et al., 1998). Acker (1994 e 1994) evidenciou que as enzimas oxidases tinham uma função central como sensores de oxigênio, baseado em evidências encontradas em espectromicroscopia, sendo reportado que o citocromo $b$ funciona como um complexo $\mathrm{NAD}(\mathrm{P}) \mathrm{H}$ oxidase, convertendo o oxigênio molecular em oxigênio singlet $\left(\mathrm{O}_{2}^{-\cdot}\right)$.

Com o intuito de identificar um sensor para o oxigênio, os pesquisadores voltaram-se novamente à fisiologia das mitocôndrias. Os resultados destes novos experimentos demonstraram que a mitocôndria tem um papel importante nas sinalizações intracelulares (VAN DER VLIET e CROSS, 2000; BICKLER e BUCK, 1998), identificando o monóxido de carbono ligado a uma heme proteína, o citocromo $_{a 3}$, no interior da membrana mitocondrial. Esta heme proteína presumivelmente estaria localizada externamente à membrana mitocondrial, com baixa afinidade ao $\mathrm{O}_{2}$ e relativa alta afinidade ao $\mathrm{CO}$ (lembrando que o citocromo converte $\mathrm{O} \mathrm{H}_{2} \mathrm{O}_{2}$ em 2 moléculas de água $\mathrm{H}_{2} \mathrm{O}$, sendo o último citocromo da seqüência doadora do par de elétrons para o oxigênio). Desta maneira invertida, como descrito pelos autores, o citocromo a3 pode converter o peróxido de hidrogênio em radicais hidroxila.

Isto sugere que, em uma determinada situação, como no estado de hipóxia, a enzima citocromo oxidase sofre uma redução de sua cinética e localização, podendo alterar o estado redox no interior da mitocôndria, elevando assim a produção de espécies reativas de oxigênio.

Duranteau et al. (1998) também avaliaram a ação das espécies reativas de oxigênio produzidas pelas mitocôndrias como segundos mensageiros na sinalização, 
ligando a sua detecção à resposta funcional das células. Foi observado que as mitocôndrias respondem às variações da pressão do oxigênio $\left(\rho^{\circ}\right)$, aumentando a produção de ROS, o que sugere que as enzimas citocromo oxidase podem ser consideradas sensores do oxigênio.

Chandel et al. (1998), com o objetivo de relacionar a hipóxia e o monóxido de carbono $(\mathrm{CO})$ à ação de alguns fatores de transcrição em relação ao aumento da produção das ROS, testaram a ação da mitocôndria como um sensor de oxigênio durante a hipóxia. Concluíram que a mesma ativa fatores de transcrição relacionados ao aumento das ROS via sinalização mitocôndria-dependente, enquanto que o $(\mathrm{CO})$ também ativa fatores de transcrição independentemente da via mitocondrial.

A hipótese da existência de um ou mais sensores de oxigênio que transmitam sinais químicos intracelulares é condizente com a noção de que há uma unificação dos mecanismos envolvidos na regulação dinâmica da transdução de sinais em resposta às variações da pressão do $\mathrm{O}_{2}$ para o interior do núcleo (HOCHACHKA et al., 1996). Em resposta à média das variações de pressão de oxigênio $\left(\Delta \rho \mathrm{O}_{2}\right)$, existe uma ação coordenada de expressão gênica necessária para conferir uma resposta adequada para a hipóxia ou a hiperóxia (ARRIGO, 1993; BUNN e POYTON, 1996; HADDAD et al., 2002; REMACLE et al., 1995). Esta regulação fisiológica da pressão do $\mathrm{O}_{2}$ é importante para monitorar uma resposta celular adequada frente às variações externas, com o objetivo de desenvolver respostas especificas, adaptando as células ou o tecido às variações externas (ALDER et al., 1999; ARRIGO, 1999; BUNN e POYTON, 1996; YOSHIDA et al., 1999; HADDAD et al., 2000; HADDAD et al., 2001).

Haddad et al. (2002) e (2004) sugerem que duas proteínas são aptas a serem classificadas como sensores de estresse: a primeira é o fator induzido pela hipóxia

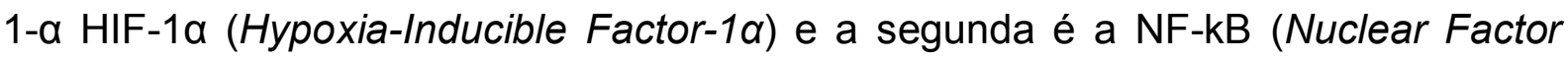
kappa-Beta) ou fator nuclear kappa beta k $\beta$. A primeira é um fator de transcrição que é expresso em condições fisiológicas de hipóxia (BALDWIN, 2001; WANG e SEMENZA, 1995; ACKER, 1994; WENGER e GASSMANN, 1997; HOCHACHKA, 1996; CHANDEL e SCHUMACKER, 1999; CHANDEL et al., 2000; WAYPA et al., 2001; EHLEBEN et al., 1998; PORWOL et al., 2001; PRABHAKAR e OVERHOLT, 2000; JIANG et al., 1996; LEE et al., 1997; SALCEDA e CARO, 1997; ZHU e BUNN, 2001; MAXWELL e RATCLIFFE, 2002). A segunda é um fator de transcrição 
dimérico amplamente estudado, relacionado às respostas celulares em um ambiente de estresse (ARRIGO, 1999; SEN e PACKER, 1996; SEN e BALTIMORE, 1996; SCHRECK et al., 1992; BUNN E POYTON, 1996; CARTER et al., 1998; MEISTER, 1998).

\subsection{FATOR NUCLEAR KAPPA-BETA (NF-kB)}

O fator nuclear KB (NF-kB) foi descoberto via interação com 11 pares de base na cadeia leve do DNA de células B, por Baltimore e colaboradores, em 1986, relacionando-se com o aumento da produção da cadeia kappa da imunoglobulina (AGGARWAL et al., 2004). Os membros desta família de proteínas dividem uma estrutura homóloga com uma oncoproteína retroviral v-Rel, resultando na classificação NF-kB/Rel (GILMORE, 1999). O fator de transcrição kappa Beta compreende um conjunto de fatores de transcrição envolvido na promoção de expressão de mais de 150 genes participantes de uma ampla variedade de processos biológicos como o de resposta imune, inflamação e reabsorção óssea. Está também envolvido em processos patológicos como a AIDS, oncogenêse, diabetes, patologias coronarianas e doenças neurodegenerativas, como Alzheimer. A ativação de NF-kB não possibilita somente a transformação maligna e progressão neoplásica, mas fornece também um mecanismo pelo qual células neoplásicas tornam-se resistentes aos quimioterápicos (MOYNAGH, 2005; YAMAMOTO e GAYNOR, 2004; KUMAR et al., 2004; AGGARWAL, 2004; PERKINS, 2004; RAVI e BEDI, 2004).

A família NF-kB é composta de cinco proteínas: p50, p52, c-Rel, RelB e RelA (p65). Estas proteínas são conservadas (presentes no diferentes filos) desde a Drosophila melanogaster até os humanos e são relacionadas através de um domínio $\mathrm{N}$-terminal, chamado $\mathrm{RH}$ (Rel Homology). O domínio RH medeia suas dimerizações, sua interação com inibidores específicos, translocação para o núcleo e ligação ao DNA (LI e STARK, 2002; DOLCET et al., 2005; MOYNAGH, 2005; YAMAMOTO e GAYNOR, 2004; KUMAR et al., 2004; AGGARWAL, 2004; PERKINS, 2004; RAVI e BEDI, 2004)

As proteínas NF-kB podem ser englobadas em dois grandes grupos. $O$ primeiro grupo é composto pelas proteínas p105 e p100. Ambas possuem um domínio C-terminal, que contem múltiplas cópias repetidas de anquirinas (uma 
proteína de ligação), o qual atua reprimindo a atividade da endonuclease. Membros deste grupo não funcionam como fatores de transcrição (LI e STARK, 2002). Quando os segmentos contendo anquirinas são alvo de proteólise, pelo proteossoma ocorre a transformação da proteína p105 em p50 e da proteína p100 em p52, gerando proteínas ativas, o que significa dizer que as mesmas têm uma capacidade transcricional (DOLCET et al., 2005; MOYNAGH, 2005; YAMAMOTO e GAYNOR, 2004; HACKER e KARIN, 2002; AGGARWAL, 2004; PERKINS, 2004; RAVI e BEDI, 2004).

O segundo grupo de proteínas da família NF-kB inclui a p65 (RelA), Rel (cRel) e RelB. As proteínas deste segundo grupo, além do domínio $\mathrm{RH}$, possuem um ou mais domínios TAD (Transcricional Activation Domains) na região C-terminal. Os domínios TAD promovem transcrição por facilitar o recrutamento de co-ativadores e deslocamento de repressores (LI e STARK, 2002; HAYDEN e GHOSH, 2004; MOYNAGH, 2005; YAMAMOTO e GAYNOR, 2004; HACKER e KARIN, 2002).

As proteínas da família NF-kB formam homo e heterodímeros, onde as formas ativas mais comuns são p50/RelA ou p52/RelA. Outros exemplos de homo e heterodímeros possíveis são: a proteína p65/p50, RelB/p100, p52/p50, c-Rel com p50, ou p65, e p65/p65, p65/p50, p65/p52, p52/c-Rel, p50/c-Rel, p65/c-rel, RelB/p50, RelB/p52, c-rel/c-rel (LI e STARK, 2002; HAYDEN e GHOSH, 2004). Convencionouse chamar ss formas p105/p50 de NF-kB1 e a apresentação na forma p52/p100 de NF-kB2 (HAYDEN e GHOSH, 2004; MOYNAGH, 2005; AGGARWAL, 2004; RAVI e BEDI, 2004). A NF-kB foi originalmente relacionado ao heterodímero p50-p65 (MOYNAGH, 2005; KUMAR et al., 2004; LI e STARK, 2002).

Em células não estimuladas, proteínas da família NF-kB apresentam-se como hétero ou homodímeros, seqüestradas no citoplasma em função da associação não covalente com membros da família de proteínas inibitórias IKB (LI e STARK, 2002; DOLCET et al., 2005; MOYNAGH, 2005; YAMAMOTO e GAYNOR, 2004; SCHUCHMANN e GALLE; 2002; KUMAR et al., 2004). A família IkB apresenta cinco membros: IkBa, IkBß, bcl-3, IkBE e IkBy, que possuem de cinco a sete anquirinas que ligam-se ao domínio $\mathrm{RH}$ das proteínas NF-kB, inibindo, dessa maneira, a interação com o DNA (HAYDEN e GHOSH 2004; DOLCET et al., 2005; MOYNAGH, 2005; YAMAMOTO e GAYNOR, 2004; HACKER e KARIN, 2002; AGGARWAL, 2004; RAVI e BEDI, 2004), regulando também a atividade NF-kB, ao entrar no 
núcleo onde se liga à subunidade p65 e a conduz para o citoplasma, o que reduz, desse modo, os níveis de p65 no núcleo e a atividade de NF-kB (WU, 2005).

\subsubsection{Via de Sinalização}

Embora não estejam completamente definidos todos os modos de ativação de IKK, acredita-se que o complexo IKKa/ß/Y é indispensável para ativação de NF-kB. Dentre os reguladores negativos de NF-kB, a proteína A20 afeta a atividade transcricional de NF-kB, induzida por TNFa, independente de sua localização nuclear. Não está claro, entretanto, se a A20 afeta a atividade de IKK $\beta$ ou bloqueia a degradação da IkB (HAYDEN e GHOSH, 2004).

É oportuno mencionar a via clássica ou canônica de ativação de NF-kB: dímeros contendo Rel-A ou c-Rel associados a p50, encontram-se inativos no citoplasma por estarem interagindo com proteínas IKB. Esta via é disparada por citocinas pró-inflamatórias e infecções virais. Após ativação, a sub-unidade IKK $\beta$ é a maior responsável pela fosforilação da IKB.

Após a fosforilação, as proteínas IkB sofrem ubiquitinização pelo proteossoma e NF-kB move-se para o núcleo, onde atua como fator transcricional (DOLCET et al., 2005; MOYNAGH, 2005; HACKER e KARIN, 2002).

Já a via alternativa, é ativada por membros da família do fator de necrose tumoral, como o BAF ( $B$ cell Activating Factor), expresso em macrófagos, células dendríticas e células $B$; ligante de CD40, encontrado em macrófagos, células dendríticas, células epiteliais e células $B$ e T; e LT $\beta R$, presente em linfócitos T. Os dímeros contendo as subunidades RelB-p52 (precursor RelB-p100) são os alvos principais. Nessa via, a NIK ativa a IKKa que, então, pode fosforilar a p100 que, por sua vez, sofre proteólise e transforma-se na forma p52 madura. O dímero move-se para o núcleo, onde pode ativar um gene alvo específico (DOLCET et al., 2005; MOYNAGH, 2005; YAMAMOTO e GAYNOR, 2004; HACKER e KARIN, 2002; RAVI e BEDI, 2004).

A proteína IKBa pode ser alvo de degradação, além das proteínas IKKa e IKKß, amparada pela proteína CK2 (Casein Kinase-II), uma serina-treonina quinase que fosforila a IKBa na região C-terminal, local distinto da fosforilação das IKKs que fosforilam na região N-terminal (RAVI e BEDI, 2004). 


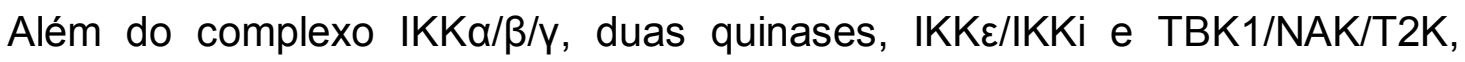
foram associadas à ativação de NF-kB. As proteínas IKKع/IKKi estão envolvidas na ativação de células $T$ e a proteína TBK1/NAK/T2K pode estar envolvida na ativação de NF-kB, em resposta ao PDGF (Platet Derivated Growth Factor). As evidências na literatura apontam que a atuação destas duas proteínas na ativação NF-kB ocorre independente e abaixo da cascata que leva à degradação da IkB (LI e STARK, 2002).

Embora os dímeros que fazem parte da via clássica (RelA-p50, cRel-p50, RelB-p52) sejam os mais comumente produzidos, outros tipos de homodímeros (p50-p50 e p52-p52) e heterodímeros (c-Rel-RelA, c-Rel-c-Rel) também são produzidos, possuindo, cada dímero de NF-kB, provavelmente uma função regulatória distinta (DOLCET et al., 2005). A ativação diferencial de sub-unidades de NF-kB pode resultar em ajustes distintos dos genes, através de diferentes ligações ao DNA (PERKINS, 2004).

A fosforilação e degradação de I-kB têm com conseqüência a liberação da NF-kB, porém esta perda do inibidor não é suficiente para ativar a transcrição. $A$ proteína p65 possui uma região específica a ser fosforilada pela quinase-A (sobre o resíduo serina 276). A fosforilação desse local é necessária para uma eficiente ligação à proteína ativadora transcricional CBP (c-AMP Binding Protein). A proteína quinase-A está ligada ao complexo NF-kB inativo. Após degradação da IkB, a proteína quinase-A fosforila a p65, ocasionando uma mudança na conformação dessa proteína, permitindo sua interação com a CBP (LI e STARK, 2002).

Outra proteína implicada na fosforilação de p65 é a CKII (Casein Kinase II) ou quinase caseína II (MOYNAGH, 2005). A proteína IkB protege a p65 da fosforilação por CKII, que está constitutivamente ativada; porém, sinais que conduzam à degradação de IkB expõem o local de fosforilação de p65 para CKII. Dessa maneira, pelo menos duas quinases são capazes de fosforilar a p65 em diferentes resíduos, aumentando a atividade transcricional da NF-kB (LI e STARK, 2002).

As proteínas PI3K (Phosphatidylinositol 3'-OH Kinase) e Akt, também chamada de Pkb (Protein Kinase b), podem promover a ativação da NF-kB, induzida por TNFa e Interleucina 1 (IL-1), através da fosforilação e ativação da subunidade p65. A proteína Akt tem sido implicada, também, na ativação da NF-kB induzida pela proteína Ras através da fosforilação e ativação da IKKß, p38 e MAPK (MitogenActivated Protein Kinase), permitindo posteriormente a ativação de p65 e CK2, que 
fosforila diretamente a $1 \mathrm{kBa}$. Recentemente, tem-se mostrado também que a ativação da proteína Akt estimulada por IL-1 ocasiona a fosforilação da subunidade p50 da NF-kB (LI e STARK, 2002; RAVI e BEDI, 2004).

$A$ atividade da NF-kB é também regulada através de modificações covalentes que alteram a habilidade dos dímeros desta endonuclease de ligarem-se ao DNA e recrutar co-ativadores. Estímulos dependentes da fosforilação de p65 foram os primeiros eventos reguladores reconhecidos após ocorrer a degradação de lkB. Tanto p65 como c-Rel possuem um local no resíduo Ser 276 para interação com a proteína PKAc (Protein Kinase A dependent-c-AMP) (MOYNAGH, 2005; RAVI e BEDI, 2004).

A PKA encontra-se associada ao complexo NF-kB/lkB no citoplasma e a degradação da IkB ativa PKA que posteriormente fosforila a p65 no resíduo Ser 276. A fosforilação de p65 por PKA desempenha uma função dupla: aumenta a eficiência da ligação da p65 ao DNA e possibilita um local adicional de interação para os coativadores transcricionais CBP/p300. A acetilação da p65 por CBP/300 prolonga a ligação da NF-kB, por prevenir interação com o lkB. Este modelo exige que a p65 seja desacetilada por HDAC-3, que interage diretamente com p65, antes da ligação à IkB e exportação para o citoplasma (HAYDEN e GHOSH, 2004; RAVI e BEDI, 2004).

Respostas individuais da NF-kB dependem de uma onda de ativação e inativação de vários membros da família NF-kB, em função da seletividade dos complexos IKK para diferentes IKBs, assim como pelas diferentes regulações realizadas pela IKB nos dímeros da NF-kB. As vias mais estudadas relacionadas à ativação da NF-kB incluem os seguintes receptores: TNFR (TNF Receptorassociated factor) ou receptor relacionado a TNFa; EGFR (Epidermal Growth Factor Receptor); receptores do fator de crescimento de insulina; TLR / IL1 / IL-1-8 (TollLike Receptors / Interleucina 1 / Interleucina 1 e 8 ); e BCR (B-Receptor Cellular), os dois últimos relacionados com a atuação na resposta imune (HAYDEN e GHOSH, 2004; DOLCET et al., 2005; MOYNAGH, 2005).

Uma vez estimulados, estes receptores desencadeiam uma seqüência de sinais envolvendo a ativação das IKKs e posterior ubiquitinização da IKBa. A superfamília de receptores TNF pode mediar a carcinogênese através da indução da proliferação, invasão e metástase de células tumorais. Esta superfamília de proteínas é considerada a mais potente ativadora da NF-kB, incidindo em pelo 
menos 19 ligantes e 29 receptores, exibindo uma diversidade tecidual acentuada. Através da ativação da NF-kB, a sinalização via TNF regula diretamente a expressão de genes anti-apoptóticos: clAP1/2 e Bcl-XL (HAYDEN e GHOSH, 2004; DOLCET et al., 2005; AGGARWAL, 2004).

A ativação do complexo IKK mediada por TNFa, que envolve receptores TNF$R 1$, tem sido extensamente investigada. A sinalização relacionada aos receptores TNF requer adaptadores intracelulares para posterior ativação da NF-kB. Uma vez ativado, o complexo libera o seu domínio SODD (Silencer Of Death Domain), um inibidor endógeno da atividade de TNF. Após a liberação do SODD, a proteína TRADD (TNRF Receptor-Associated Death Domain protein) é associada ao receptor TNF (HAYDEN e GHOSH, 2004).

A proteína TRADD posteriormente recruta proteínas da família TRAF (TNF Receptor Associated Factor), composta pelas proteínas TRAF2, TRAF3 e TRAF5. Alguns estudos têm demonstrado que TRAF2 recruta IKKa e IKK $\beta$ após tratamento com TNFa. A TRAF2 também interage com RIP1 (Receptor Interacting Protein 1).

RIP1 pode recrutar IKK ao unir-se à subunidade NEMO, de maneira independente de TRAF2 e, após ligação, induzir auto-fosforilação de IKK (YAMAMOTO e GAYNOR, 2004). RIP1 é essencial para a ativação de NF-kB induzida por TNFa, uma vez que o recrutamento de IKK por TRAF2 na ausência de RIP1 não é suficiente para a ativação de IKK. Por fim, é interessante mencionar que RIP1 pode ser recrutada diretamente por TRADD (HAYDEN e GHOSH, 2004; MOYNAGH, 2005).

Um intrigante aspecto da via de sinalização de TNF é sua habilidade de ocasionar tanto apoptose como sobrevida. Tem-se mostrado que a ativação prolongada de JNK/AP-1 permite a apoptose e a indução da NF-kB permite a síntese de certas proteínas que inibem a ativação de JNK/AP1. Um desses fatores ativados por NF-kB é a proteína GADD45ß, a qual inibe a via de ativação de JNK por bloquear a quinase MKK7. Outra proteína que inibe a ativação de JNK que é induzida por NF-kB é a XIAP (X-chromosome-linked Inhibitor of Apoptosis Protein). A proteína XIAP, além de bloquear JNK, inibe também muitas caspases próapoptóticas (HAYDEN e GHOSH, 2004).

A NF-kB é também ativada via EGFR (Epidermal Growth Factor receptors). EGFR corresponde a uma família de receptores tirosino-quinase que incluem os seguintes componentes: EGFR (ErbB-1, HER), Neu (ErbB-2, HER2), ErbB-3 (HER3) 
e ErbB-4 (HER4). Expressão aumentada de membros da família EGFR ou HER2/Neu tem sido observada em uma proporção de cânceres humanos e está relacionada com aumento de metástase, resistência à apoptose e prognóstico desfavorável (RAVI e BEDI, 2004).

A NF-kB não é encontrada constitutivamente ativa em células normais, exceto em células $T$ proliferantes, células $B$, monócitos e astrócitos (AGGARWAL, 2004). A NFkB está relacionada com muitas neoplasias humanas, por regular também a expressão de várias moléculas envolvidas em muitos processos que desempenham um papel chave no desenvolvimento e progressão do câncer, controlando o ciclo celular, proliferação, adesão, migração, angiogênese, apoptose e metástase (DOLCET et al., 2005; KUMAR et al., 2004; AGGARWAL, 2004; PERKINS, 2004).

A ativação constitutiva ou aberrante de NF-kB tem sido associada a muitas neoplasias malignas humanas, incluindo linfomas de células $T$, carcinomas de mama, carcinomas de células pequenas do pulmão, câncer da tireóide, mieloma múltiplo, melanoma, carcinomas de cólon, próstata e renal (DOLCET et al., 2005; KUMAR et al., 2004; AGGARWAL, 2004). A supressão da atividade de NF-kB nessas neoplasias inibe a proliferação das células, promove a parada do ciclo celular e permite a apoptose, indicando um papel importante de NF-kB na proliferação celular neoplásica e sobrevida destas células (AGGARWAL, 2004).

\subsubsection{NF-kB e Regulação da Apoptose}

Células neoplásicas de quase todos os tecidos adquirem a característica de manter a NF-kB ativa indefinidamente devido à sua habilidade de possibilitar e manter a transformação maligna. Além disso, favorecem o mecanismo pelo qual as células cancerígenas escapam do sistema imune e resistem à quimioterapia e à radioterapia (RAVI e BEDI, 2004).

Nessa linha de pensamento, convém mencionar que a NF-kB pode regular a expressão de proteínas que regulam a via de apoptose (MOYNAGH, 2005; SCHUCHMANN e GALLE; 2002). Uma dessas proteínas é a FLIP (FLICE-Like Inhibitory Protein), que se mostra semelhante à caspase 8, porém perde sua atividade de protease e compete com esta caspase pelo DISC (Death-Inducing Signaling Complex), inviabilizando a apoptose via Fas ligante. Outras proteínas, induzidas por NF-kB, da cascata de sinalização de TNF- $\alpha$, como TRAF2 e TRAF6, 
neutralizam a ação apoptótica da caspase 8. Associadas, estas proteínas podem conferir resistência à apoptose (DOLCET et al., 2005; SCHUCHMANN e GALLE; 2002; RAVI e BEDI, 2004).

A NF-kB pode, também, induzir a expressão de inibidores da apoptose (IAPS Inhibitors of Apoptosis) e de alguns membros da família anti-apoptótica Bcl-2 (B-cell lymphocyte/leukemia-2). As IAPs, clAp2 e XIAPs suprimem a apoptose induzida através de inibição direta de caspases 3, 6 e 9 CAP (Cysteine Aspartate Proteases). A NF-kB pode, ainda, atenuar a expressão de proteínas pró-apoptóticas, como a BAX membro da família Bcl-2 (DOLCET et al 2005, SCHUCHMANN e GALLE; 2002, YAMAMOTO e GAYNOR, 2004; PERKINS, 2004; RAVI e BEDI, 2004).

O antagonismo das funções de transcrição que ocorre entre p53 e NF-kB envolve competição com co-ativadores como p300 e CBP (CREB [CAMPResponsive Element-Binding protein] Binding Protein). Além disso, a proteína p53 reprime a expressão de Bcl-3, um co-ativador transcricional da subunidade p52 de NF-kB, alterando, deste modo, a forma ativadora p52/Bcl-3 para o complexo repressor p52/HDAC1. Finalmente, a ativação de NF-kB mediada por IKK2 tem mostrado proteger células com apoptose induzida por dano ao DNA, através do aumento dos níveis de uma oncoproteína Mdm2 (Mouse Double Minute 2) (DOLCET et al., 2005; PERKINS, 2004; RAVI E BEDI, 2004).

Células NK (natural killer) e CTLs (Cytotoxic $T$ Lymphocytes) induzem apoptose de células neoplásicas através de dois mecanismos: pela liberação de granzimas $B$ (enzimas que induzem a apoptose) por uma indução à clivagem e à ativação de caspases 3, 6, 7, 8, 9 e 10; e pela ligação dos receptores TNF de morte celular (como TRAIL-R1/R2 e CD45) nas células alvos por ligantes (FasL, Apo2L/TRAIL) expressados por células NK ou CTLs. Tais ligantes e receptores são expressos por estímulo dependente de INF (Interferon). A NF-kB reduz a morte celular induzida por células NKs ou CTLs através da estimulação de c-FLIP, Bcl-X $\mathrm{X}_{\mathrm{L}} \mathrm{e}$ IAPS (HAYDEN e GHOSH, 2004; RAVI e BEDI, 2004).

Ravi e Bedi (2004) relataram também que IKKß, a subunidade responsável pela via clássica de ativação de NF-kB, é inativada por proteólise mediada por caspase-3. Durante apoptose induzida por TNF-a, as caspases podem, também, remover o domínio terminal $\mathrm{NH} 2$ de $\mathrm{I} \mathrm{kB} \alpha$, gerando fragmentos de $\mathrm{I} \mathrm{kB} \alpha$ resistentes à degradação induzida por TNF- $\alpha$. Esta citocina (TNF- $\alpha$ ) ativa os receptores de morte celular, podendo induzir a clivagem de Rel-A mediada por caspase (RAVI e BEDI, 
2004). Desta maneira, a proteólise da IKKß-IKBa-RelA mediada por caspases pode ser o mecanismo pelo qual as mesmas concluem a ativação de NF-kB e removem o obstáculo para suas ativações, para posteriormente ligarem-se a um promotor nuclear .

Como mencionado acima, a NF-kB é responsável por resistência à apoptose. Entretanto, tem sido especulado que a NF-kB pode exercer um papel tanto pró quanto antiapoptose, dependendo dos níveis de RelA e c-Rel (DOLCET et al., 2005). Perkins (2004) relata que a sub-unidade Rel A (p65) de NF-kB é requerida para apoptose dependente de p53, afirmação que mostra que NF-kB pode contribuir, também, com a supressão tumoral.

Perkins (2004) sugere, ainda, que o papel supressor de tumor da NF-kB esteja relacionado com a associação das subunidades de NF-kB (p52-p52 e p50RelA, estimuladas por p53 e ARF) com HDAC1 (histone deacetylase-1), um complexo repressor da atividade de transcrição de NF-kB, resultando em inibição da promoção de proteínas que colaboram com o crescimento neoplásico, como, por exemplo, ciclina D1 e Bcl-xL.

Nos estádios precoces de transformação maligna, a NF-kB teria a função de supressor tumoral, mais do que de promotor. Com o acúmulo de mutações, a NF-kB passaria de fato a desempenhar um papel de promotor e não mais de supressor tumoral, em decorrência da inativação das proteínas p53 e ARF, que estimulariam a atividade supressora de NF-kB. No entanto, o mecanismo básico destes efeitos contraditórios ainda precisa ser elucidado (PERKINS, 2004; RAVI e BEDI, 2004).

\subsubsection{Regulação da Proliferação da Angiogênese.}

A promove progressão do ciclo celular por regular a expressão de vários genes envolvidos na maquinaria do ciclo celular, como as ciclinas D1, D2, D3 e E, além de c-myc e c-mycb. A expressão de ciclina D1 induzida por NF-kB parece ser o elemento chave no desenvolvimento de glândulas mamárias e carcinogênese de mama (DOLCET et al., 2005; YAMAMOTO e GAYNOR, 2004; KUMAR et al., 2004; AGGARWAL 2004; RAVI e BEDI, 2004).

Convém acrescentar que NF-kB induz a expressão de moléculas de adesão como ICAM-1 (Intercellular Adhesion Molecule), E selectina, ELAM-1 e VCAM-1 (Vascular Cell Adhesion Molecule - 1) - e metaloproteinases - como MMP-2 e MMP- 
9 - envolvidas na degradação das proteínas da matriz extra-celular e nas metástases. Alguns fatores angiogênicos, incluindo o VEGF (Vascular Endothelial Grown Factor), MCP-1, IL-8 e TNF produzidos por macrófagos e neutrófilos, são também dependentes da ativação de NF-kB, assim como regulam genes relacionados à vasodilatação, como INOS (Inducible Nitric Oxide Synthase) (DOLCET et al., 2005; YAMAMOTO e GAYNOR, 2004; AGGARWAL, 2004; PERKINS, 2004).

Alguns oncogenes medeiam seus efeitos através da interação com NF-kB, entre os quais podemos citar os oncogenes Ras, c-myc e Pim-2 (AGGARWAL, 2004). Ao lado disto, numerosas citocinas reguladas por NF-kB são fatores de crescimento para células neoplásicas: TNF é um fator de crescimento para linfomas de Hodgkin, linfoma de células $T$ cutâneo, gliomas e IL-6, que funciona como fator de crescimento para mieloma múltiplo. Além disto, o EGF é um fator de crescimento para cânceres de mama e próstata, que medeiam seus efeitos, em parte, através da ativação de NF-kB (AGGARWAL, 2004).

O óxido nítrico, que também influencia a habilidade do tumor de se metastizar, possui expressão dependente de NF-kB (AGGARWAL, 2004). Além disto, a NF-kB induz a expressão de ciclooxigenase-2 (COX2), que é importante para o crescimento neoplásico, como observado em carcinomas de colo, uma vez que a COX-2 induz a expressão de alguns fatores angiogênicos (VEGF, FGF, PDGF, TGF- $\beta$ ) e de seus receptores na superfície das células endoteliais (DOLCET et al., 2005; YAMAMOTO e GAYNOR, 2004; PERKINS, 2004; RAVI E BEDI, 2004).

\subsection{Regulação Redox (NF-kB)}

O estado redox celular regula vários aspectos das funções celulares como proliferação, atividade, crescimento, inibição e morte celular (HADDAD e LAND, 2000, RAHMAN e MACNEE, 2000; RAHMAN, 2001; SEN, 1999; CHRISTMAN, 2000; GIUS et al., 1999; HIROTA et al., 1999; JANSSEN-HEININGER et al., 2000; HUTTER e GREENE, 2000; GOSSET, 1999; GRIFFITH e MEISTER, 1979; MEISTER, 1988; PARMENTIER, 2000). O termo estresse oxidativo, como já foi citado anteriormente, indica o estado antioxidante de células ou tecidos e as alterações sofridas quando estes são expostos a fatores oxidantes. Cada vez mais evidências são acumuladas propondo que o balanço entre oxidantes e antioxidantes 
está envolvido na saúde e longevidade do indivíduo e, o contrário, a ruptura deste balanço, pode provocar desordens funcionais e patologias. $O$ estresse oxidativo pode desempenhar um papel muito importante na iniciação e propagação de muitas patologias, doenças neuro-degenerativas como Parkinson e Alzheimer, doenças cardiovasculares e auto-imunes e também nas injúrias de isquemia e reperfusão.

A regulação do estado redox intracelular é mantida através de enzimas como a glutationa, catalase, superóxido dismutase, glutationa peroxidase e tioredoxina (TRX). A TRX e a TRX-redutase são encontradas em todos os níveis celulares e também se constituem fisiologicamente nas maiores proteínas NADPHdependentes. Estas enzimas são doadoras de hidrogênio, principalmente aos ribonucleotídeos redutase, enzimas essenciais à síntese de DNA, e também a um amplo número de funções na regulação do estado redox e na defesa contra agentes que provocam o estresse oxidativo.

A tiorexina foi bem estudada na regulação da atividade dos receptores de glicocorticóides e em um grande número de fatores de transcrição com a NF-kB e a proteína ativadora-1 (AP-1). A glutaredoxina (GRX), junto com o NADPH, glutationa $(\mathrm{GSH})$ e a glutationa peroxidase, formam o sistema glutaredoxina, essencial para a regulação do estado redox intracelular (TANAKA, 2001).

O papel da sinalização redox na regulação e expressão gênica está bem documentado (ALDER, 1999; ARRIGO, 1993; CIMINO et al., 1997; SUN e OBERLEY, 1996; TANAKA et al., 1997; LEGRAND-POELS et al., 1997; GINNPEASE e WHISLER, 1998; TEWES et al., 1997; VALLE-BLAZQUEZ et al., 1997). Neste capítulo, será analisada especificamente a NF-kB e seu controle pelo processo redox. Como já foi visto anteriormente, o primeiro passo para a ativação da NF-kB é sua dissociação em cascata das IkBs. Após esta dissociação, porém, a NFkB tem de passar por um caminho onde esta endonuclease sofre interferências redutoras da glutationa (GSH) e da tioredoxina (TRX). Está bem estabelecido que a NF-kB não pode se ligar ao sítio kB da seqüência do DNA se este não estiver reduzido. A NF-kB parece ter uma nova estrutura de ligação com o DNA chamada $\beta$ barril (ou, em inglês, $\beta$-barrel), um grupo de proteínas semelhante à conformação das proteínas folhas $\beta$ (ou, em inglês, $\beta$ sheets), porém com uma estrutura mais alongada para promover a ligação ao DNA. Nesta conformação $\beta$-barril, há uma alça na porção terminal, que se intercala com bases de nucleotídeos e é considerada para realizar o contato direto com o DNA. Esta alça, que se liga ao DNA, contém a 
cisteína 62, que tem como função ligar-se ao regulador redox, que pode ser a GSH ou a TRX, utilizada como doador de prótons. Observou-se a estrutura em 3D da molécula da TRX, especialmente a alça de ligação do DNA à p50, utilizando uma análise de NMR (Nuclear Magnetic Resonance) ou ressonância magnética nuclear (HAYASHI et al., 1993; JIN et al., 1997; QIN et al., 1995). A região da alça pode ser localizada sobre a superfície da tioredoxina, que contém uma atividade redox, podendo então estabilizar a ligação da proteína p50 ao DNA. É provável que esta ligação reduza a cisteína por doação de prótons (HIROTA et al., 2001; JIMENEZ et al., 2000; JIMENEZ, 2001).

A NF-kB in vivo pode ser inibida por agentes que modificam os grupos sulfidrilas livres da glutationa e da tioredoxina (HADDAD et al., 2000; RAHMAN, 2000; HIROTA et al., 2000). Por exemplo, a ligação da NF-kB ao DNA pode ser suprimida após um tratamento com $N$-etilmaleimido, um agente alquilante. Isto foi possível pela modulação do estado redox da célula, impedindo a ligação efetiva da NF-kB ao DNA (MOLITOR et al., 1991; TOLEDANO e LEONARD, 1991).

Outro estudo interessante realizado por Matthews e Hay (1995) e Israel et al. (1992) em células U937, foi o da utilização de um antioxidante potente, o BHA (Butylated Hydroxyanisole), em células estimuladas por TNF e peróxido de hidrogênio. Observou-se que, nas células estimuladas por TNF e tratadas com BHA, houve um aumento dos grupos tiois, mas não de glutationa. Portanto, a TNF foi capaz de modificar os níveis de grupos tiois intra-celulares. Além disto, o estresse oxidativo obtido pela adição de $\mathrm{H}_{2} \mathrm{O}_{2}$ e tratadas com BHA não foi possível observar a ativação da NF-kB. Estas observações sugerem que a TNF e $\circ \mathrm{H}_{2} \mathrm{O}_{2}$ não podem levar, por si só, à ativação da NF-kB, embora induzam a mudanças do estado redox no interior celular. Porém, a lipo-peroxidação pode induzir a completa ativação da NF-kB (WESTENDO et al., 1995; WEINGARTEN et al., 2001; WARIS et al., 2001).

Todos estes dados anteriormente citados indicam que esta endonuclease NFkB é ativada conforme o estado redox intracelular. Este estado é sensível a variações externas, principalmente ao estresse provocado pelo processo inflamatório, devido, sobretudo, ao conjunto de alterações que a inflamação provoca no tecido e principalmente no interior das células (ANDERSON et al., 1994). 
6 Conclusão 
De acordo com o que foi verificado nesse trabalho e com os objetivos iniciais, pode-se concluir que:

1- O Método de Imunohistoquímica, utilizando-se da técnica da estreptavidina-biotina, foi desenvolvido em tecido ósseo não desmineralizado e possibilitou a identificação da endonuclease NF-kB em cortical óssea de fêmures de ratos Wistar. Desta forma, foi possível a identificação e posterior semi quantificação desta endonuclease em corticais ósseas destes animais.

2- $\quad$ Foi viabilizada, assim, a identificação do pico de ativação desta endonuclease, em cortical óssea de fêmures de ratos Wistar, atingido em 6 horas, como indicam os dados obtidos nesse trabalho.

3- $\quad$ A partir do estabelecimento do pico de ativação da NF-kB em cortical óssea de ratos Wistar, foram realizados alguns experimentos nos quais, a partir dos dados que foram verificados neste trabalho, pode-se afirmar:

a) - Houve uma redução estatisticamente significativa da NF-kB em cortical óssea, quando utilizada irrigação com solução fisiológica, porém, esta redução foi localizada apenas na região Periostal, na posição zero. Na avaliação geral do comportamento desta endonuclease, não houve diferença significativa entre o grupo controle (grupo determinação do pico de ativação - atingido em 6h) e grupo implantes de titânio.

b) - Neste trabalho, não foi possível a avaliação do implante juntamente com o tecido ósseo adjacente pela técnica de Imunohistoquímica desenvolvida em tecido ósseo não desmineralizado.

c) -.Quando comparado o grupo experimental Composto Orgânico com os demais grupos, foi possível verificar estatisticamente uma redução significativa da imunorreatividade positiva para a NF-kB, 
indicando uma efetiva proteção do Composto Orgânico na manutenção do equilíbrio redox celular.

Além destas conclusões relativas aos objetivos iniciais desse trabalho, também se pode concluir, com base nos resultados obtidos, que:

4- $\quad$ O trauma cirúrgico desencadeia a ativação da NF-kB por toda a cortical óssea, não se limitando à região lesada, fato que justifica o uso do termo osteointegração;

5- $\quad$ Existe uma íntima relação entre a NF-kB e os Glicocorticóides exógenos (Dexametasona), sendo demonstrado neste trabalho um aumento estatístico significativo da imunorreatividade positiva da NF-kB quando injetada na região peritonial dos animais experimentais utilizados. 
REFERENCIAS 
ACARREGUI, M.J, BROWN, J.J, MALLAMPALLI, P.K. Oxygen modulates surfactant protein mRNA expression and phospholipid production in human fetal lung in vitro. Am. J. Physiol. v. 268, p. L818-L825, 1995.

ACKER, H. Cellular oxygen sensors. Ann. N.Y. Acad. Sci.v.718, p.3-10, 1994.

ACKER, H. Mechanisms and meaning of cellular oxygen sensing in the organism. Respir Physiol. v.95, p.1-10, 1994.

AGGARWAL, B.B. Nuclear factor-kB: The enemy within. Cancer Cell.v. 6, p. 203208, 2004.

AHN, K.S.; AGGARWAL, B.B. (Review)Transcription factor NF-kappaB: a sensor for smoke and stress signals. Ann N Y Acad Sci. v.Nov;1056. p. 218-33, 2005.

ALDER, V, YIN Z, Tew KD, Ronai Z. Role of redox potential and reactive oxygen species in stress signaling. Oncogene. v.18, p.6104-6111, 1999.

ALLEGRINI, S.J; YOSHIMOTO, M; SALLES, M.B; KÖNIG, B.J. Bone regeneration in rabbit sinus lifting associated with bovine BMP.J. Biomed. Mater. Res. Part B: Appl Biomater. v. 68B, p. 127-131, 2003.

ANDERSON, M.T; STAAL, F.J; GILTER C;HERZENBERG, L.A. Separation of oxidant-initiated and redox-regulated steps in the NF-KB signal transduction pathway Proc. Natl. Acad. Sci. U. S. A. v. 91, p. 11527-11531; 1994.

ARRIGO, A.P Free Radic. Biol. Med. v. 27, p. 936-944, 1993.

ARRIGO, A.P. Gene expression and the thiol redox state. Free Radic Biol Med. v 27, p. 936-944, 1999.

BALDWIN, A. S. The transcription factor NF-KB and human disease. J Clin Invest. .107, p3-6, 2001.

BAMBERGER, C.M; SCHULTE, H.M; CHROUSOS, G.P. Molecular determinants of glucocorticoid receptor function and tissue sensitivity to glucocorticoids. Endocr Rev. v. 17 (3), p.245-611,1996.

BERTRAM, J. E. A; SWARTZ, S. M. The law of bone transformation': a case of crying Wolff? Biol. Rev.v. 66,p.245-273, 1991.

BICKLER, P.E; BUCK, L.T. Adaptations of vertebrate neurons to hypoxia and anoxia: Maintaining critical Ca2+ concentrations. J Exp Biol. v. 201, p.1141-1152, 1998.

BOGLIOLO, L. Patologia Geral. 6a. Edição. Rio de Janeiro: Ed. Guanabara Koogan, 2000. 
BOHNSACK, B.L.; HIRSCHI, K.K. (Review) Nutrient regulation of cell cycle progression. Annu Rev Nutr.v. 24, p. 433-53, 2004.

BORASCHI, D.; CIFONE, M.G; FALK, W.; FLAD H-D, T.A; MARTIN, M.U. Cytokines in inflammation. Eur Cytokine Netw. v. 9, p.205-212; 1998.

BORG, D.C.; SCHAICH, K.M. Iron and iron-derived radicals. In Halliwell B (ed): Oxygen radicals and tissue injury. Proceedings of a Brook Lodge Symposium; 1987 Apr 27-29; Bethesda (MLD): Upjohn/Federation of American Societies for Experimental Biology, v. 20-6; 1988.

BOSKEY, A.L.; GADALETA, S.; GUNDBERG, C.; DOTY, S.B; DUCY, P.; KARSENTY, G. Fourier transform infrared microspectroscopic analysis of bones of osteocalcin-deficient mice provides insight into the function of osteocalcin. Bone. $v$. 23, p. 187-196, 1998.

BOURQUE, W.T; GROSS, M.; HALL, B.K. A histological processing technique that preserves the integrity of calcified tissues (bone, enamel), yolky amphibian embryos, and growth factor antigens in skeletal tissue. J Histochem Cytochem.v. Sep.41(9), p1429-34, 1993.

BRADBURY, M.J.; AKANA, S.F.; CASCIO, C.S.; LEVIN, N.; JACOBSON, L.; DALLMAN, M.F. Regulation of basal ACTH secretion by corticosterone is mediated by both type I (MR) and type II (GR) receptors in rat brain. J Steroid Biochem Mol Biol. v. 40(3), p.133-42,1991.

BRANEMARK, P.I.; LINDSTROM, J; OHLSSON, A. Intra-osseous anchorage of dental protheses. Scand J. Plast Reconstr Surg. v. 3, p. 1-100, 1969.

BRECHTER, A.; BERNHOLD, U.L.F; LERNER, H. Bradykinin potentiates cytokineinduced prostaglandin biosynthesis in osteoblasts by enhanced expression of cyclooxygenase-2, resulting in increased RANKL expression. Arthritis Rheum. v. Mar;56(3), p.910-23, 2007.

BUCHHOLZ, J.; HUBER, F.X.; MEEDER, P. J.; MUHR, G.; KREITZ, G.K; HERZO, G.L. Detection of high-energy phosphates in cortical bone as an indicator of bone healing and remodelling: Use of a rabbit model. J Orthop Surg (Hong Kong). Dec;12(2):205-9: 2004.

BUNN, H.F.; POYTON, O.R. Oxygen sensing and the molecular adaptation to hypoxia. Physiol Rev. v.76, p.839-885; 1996.

BURKHARDT, R. [Preparative prerequisites in clinical histology of human bone marrow. 1.Methodical studies on embedding in acrylates of lipid-rich tissue material] Blut. v. Sep;13(6), p. 337-57, 1966. 
BUTCHER, S.K.; LORD, J.M. Stress responses and innate immunity: aging as a contributory factor. Aging Cell. v. Aug;3(4), p.151-60, 2004.

CANHAO, H.; FONSECA, J.E.; QUEIROZ, M.V. [Eating habits and life styles in a Portuguese population--protective and risk factors for osteoporosis] Acta Reumatol Port. v.Oct-Dec;31(4), p.331-9, 2006.

CANO, E. MAHADEVAN, L. C. Parallel signal processing among mammaliam MAPKs. Trends Biochem Sci. v. 20, p. 117-22, 1995.

CAPLAN, A.I. Mesenchymal stem cell. J. Orthop. Res. v. 9, p. 641-650,1991.

CARTER, A.B.; MONICK, M.M.; HUNNINGHAKE, G. Lipopolysaccharide-induced NF-kappaB activation and cytokine release in human alveolar macrophages is PKC-independent and TK- and PC-PLC-dependent. Am J Respir Cell Mol Biol. v. Mar;18(3), p.384-91, 1998.

CASWELL, A.M., RUSSELL, R.G.G., WHYTE, M.P. Hyphophosphatasia: Pediatric forms. J. Pediatr. Endocrinol.v 3, p.73-92, 1989.

CHANDEL, N.S.; MCCLINTOCK, D.S.; FELICIANO, C.E.; WOOD, T.M.; MELENDEZ J.A.; RODRIGUEZ, A.M.; SCHUMACKER, P.T. Reactive oxygen species generated at mitochondrial complex III stabilize hypoxia-inducible factor-1a during hypoxia: A mechanism of oxygen sensing. J Biol Chem. v.275, p.2513025138, 2000.

CHANDEL, N.S.; SCHUMACKER, P.T. Cells depleted of mitochondrial DNA $(\rho 0)$ yield insight into physiological mechanisms. FEBS Lett. v.454, p.173-176, 1999.

CHANDEL, N.S.; SCHUMACKER, P.T. Cellular oxygen sensing by mitochondria: Old questions, new insight. J Appl Physiol. v. 88, p. 1880-1889, 2000.

CHAPPARD, D.; PALLE, S.; ALEXANDRE, C,; VICO, L.; RIFFAT, G. Bone embedding in pure methyl methacrylate at low temperature preserves enzyme activities. Acta Histochem. v.81(2), p.183-90, 1987.

CHEN, C.Y.; HUANG, Y.L.; LIN, T.H. Association between oxidative stress and cytokine production in nickel-treated rats. Arch Biochem Biophys. v.356, p.127132, 1998.

CHEN, Y.J.; KUO, Y.R.; YANG, K.D.; WANG, C.J.; SHEEN, S.M.; HUANG, H.C.; YANG, Y.J.; YI-CHIH, S.; WANG, F.S. Activation of extracellular signal-regulated kinase (ERK) and p38 kinase in shock wave-promoted bone formation of segmental defect in rats. Bone. v.Mar;34(3), p.466-77, 2004.

CHO, M.; GWAK, J.; PARK, S.; WON, J; KIM, D-E.; YEA, S.S. ET AL. Diclofenac attenuates $W n t / \beta$-catenin signaling in colon cancer cells by activation of NF-KB. FEBS letters. 579: 4213-4218; 2005. 
DROGE, W. Free radicals in physiological control of cell function. Physiol Rev. v. 82: 47-95, 2002.

DUCY, P. C.; DESBOIS, B.; BOYCE, G.; PINERO, B.; STORY, C.; DUNSTAN, E.; SMITH, J.; BONADIO, S.; GOLDSTEIN, C.; GUNDBERG, A.; KARSENTY. G. Increased bone formation in osteocalcin-deficient mice. Nature. v. 382, p. 448-452: 1996.

DURANTEAU, J.; CHANDEL, N.S.; KULISZ, A.; SHAO, Z.; SCHUMACKER, P.T. Intracellular signaling by reactive oxygen species during hypoxia in cardiomyocytes. J Biol Chem. v. 273, p.11619-11624, 1998.

DUVAL, C.; CANTERO, A.V.; AUGE, N.; MABILE, L.; THIERS, J.C.; NEGRESALVAYRE, A.; SALVAYRE, R. Proliferation and wound healing of vascular cells trigger the generation of extracellular reactive oxygen species and LDL oxidation. Free Radic Biol Med. v. Dec 15;35(12), p.1589-98, 2003.

EHLEBEN, W.; BOLLING, B.; MERTEN, E.; PORWOL, T.; STROHMAIER, A.R.; $A C K E R, H$. Cytochromes and oxygen radicals as putative members of the oxygen sensing pathway. Respir Physiol. v. 114, p.25-36, 1998.

EHRLICH, H.P.; HUNT, T.K. The effects of cortisone and anabolic steroids on the tensile strength of healing wounds. Ann Surg. v. 167, p.324-8, 1968.

FANDREY, J.; SEYDEL, F.P.; SIEGERS, C.P.; JELKMANN, W. Role of cytochrome P450 in the control of the production of erythropoietin. Life Sci. $v$. 47(2), p. 127-34, 1990.

FANG,. J. Stimulation of new bone formation by direct transfer of osteogenic plasmid. gene. Proc. Natl. Acad Sci. USA. v. 93, p. 5753-5758, 1996.

FEHRENBACH, H. Alveolar epithelia type II cell: Defender of the alveolus revisited. Respir Res. v. 2, p. 33-46, 2001.

FONDARD, O.; DETAINT, D.; IUNG, B.; CHOQUEUX, C.; ADLE-BIASSETTE, H.; JARRAYA, M.; HVASS, U.; COUETIL, J.P.; HENIN, D.; MICHEL, J.B.; VAHANIAN, A.; JACOB, M.P. Extracellular matrix remodelling in human aortic valve disease: the role of matrix metalloproteinases and their tissue inhibitors. Eur Heart J. v. Apr 12, 2005.

FORWOOD, M. R. Inducible cyclo-oxygenase (COX-2) mediates the induction of bone formation by mechanical loading in vivo. J. Bone Miner. Res. v. 11, p.16881693, 1996.

FRANK, S.; MADLENER, M.; WERNER, S. Transforming growth factors beta1, beta2, and beta3 and their recep-tors are differentially regulated during normal and impaired wound healing. J Biol Chem. v.271, p.10188-93, 1996. 
CHRISTMAN, J.W.; BLACKWELL,T. S.; JUURLINK, B.H. Redox regulation of nuclear factor kappa B: therapeutic potential for attenuating inflammatory responses Brain Pathol. v. 10, p. 153-162, 2000.

CIMINO, F.; ESPOSITO, F.; AMMENDOLA, R.; RUSSO, T. Gene regulation by reactive oxygen species. Curr. Top. Cell. Regul.v. 35, p. 123-148, 1997.

CLAY, J.R. Axonal excitability revisited. Prog Biophys Mol Biol. v.May;88(1), p.5990, 2005.

COHEN, I.K.; DIEGELMANN, R.F.; JOHNSON, M.L. Effect of corti costeroids on collagen synthesis. Surgery. v.;82, p.15-20, 1977.

CRAPO, J.D.; BARRY, B.E.; FOSCUE, H.A.; SHELBURNE, J. Structural and biochemical changes in rat lungs occurring during exposure to lethal and adaptive doses of oxygen. Am Rev Respir Dis. v. 122, p.123-143, 1980.

DEL MAESTRO, R.F. An approach to free radicals in medicine and biology. Acta Physiol Scand. v. (suppl) 492, p. 153-167, 1980.

DESAI, T.J.; CARDOSO, W.V. Growth factors in lung development and disease: Friends or foe. Respir Res.v.3, p.2-5, 2002.

DIFRANCESCO, D.; MANGONI, M.; MACCAFERRI, G. The pacemaker current in cardiac cells. In: Zipes DP and Jalife J (Eds.): Cardiac Electrophysiology. From Cell to Bedside, Philadelphia, W.B. Saunders Company, p 96-103, 1995.

DODDS, R.A.; CATTERALL, A.; BITENSKY, L.; CHAYEN, J. Abnormalities in fracture healing induced by vitamin B6-deficiency in rats. Bone. v. 7(6), p.489-95: 1986.

DOLCET, X.; LL'OBET, D.; PALLARES, J.; MATIAS-GUIN, X. NFKB in development and progression of human cancer. Virchows Arch. v.446, p. 475482. 2005.

DONATH, K. Histopathologie. In: Spiekermann, h., ed., Implantologie, 1st edition, Stuttgart, New York: p.59-80, 1994.

DONATH, K.; BREUNER, G. A method for study of undecalcified bones and teeth with attached soft tissue. J. Oral Pathol., v.11, p.318-326, 1982.

DONATH, K.; BREUNER, G. A method for study of undecalcified bones and teeth with attached soft tissue. J. Oral Pathol., v.11, p.318-326, 1982.

DONATH, K.; LAASS, M.; GÜNZL, H. J. The histopathology of different foreignbody reactions in oral soft tissue and bone tissue. Virchows Archiv. A.: Pathological Anatomy and histopathology., v.420., p.131-137, 1992. 
FRITTON, S.P.; MCLEOD, K.J.; RUBIN, C.T. Quantifying the strain history of bone: spatial uniformity and self-similarity of low-magnitude strains. J Biomech. $v$. Mar;33(3), p.317-25, 2000.

FU, K.; SARRAS, M.P JR; DE LISLE, R.C.; ANDREWS, G.K. Expression of oxidative stress-responsive genes and cytokine genes during caerulein-induced acute pancreatitis. Am J Physiol. v. 273, p.G696-G705, 1997.

GALY, A.; NÉRON, B.; PLANQUE, N.; SAULE, S.; EYCHÈNE, A. Activated MAPK/ERK Kinase (MEK-1) Induces Transdifferentiation of Pigmented Epithelium into Neural Retina. Dev Biol. v.Aug 15; 248(2), p. 251-64. 2002.

GARCIA-FERNANDEZ, L.F.; INIGUEZ, M.A.; EGUCHI, N.; FRESNO, M.; URADE, Y.; MUNOZ, A. Dexamethasone induces lipocalin-type prostaglandin D synthase gene expression in mouse neuronal cells, J. Neurochem. v. 75 , p. 460-470, 2000.

GARDĖS-ALBERT, M.; JORE, D.; FERRADINI, C. Membrane lipid peroxidation: pulse and -radiolysis in oxyradical research. In Vigo-Pelfrey C (ed): Membrane lipid oxidation. 1th ed. Santa Clara, CRC Press, p.2-30; 1991.

GARTNER, L. P.; Hiatt, J. L. Tratado de Histologia em Cores. 1. Edição. Rio de Janeiro: Ed Guanabara Koogan, 1999.

GARTNER, L.P: HIATT, J.I. Histologia Básica. McGraw-Hill Interamericana 1999.

GILMORE, T. D. (Review)The Rel/NF-kappaB signal transduction pathway: introduction. Oncogene. v. Nov 22;18(49), p. 6842-4, 1999.

GINN-PEASE, M.E.; WHISLER, R.L. Redox Signals and NF-KB Activation in T Cells. Free Radic. Biol. Med. v. 25, p. 346-361; 1998.

GIORDANO, R.; DI VITO, L.; LANFRANCO, F.; BROGLIO, F.; BENSO, A.; GIANOTTI, L.; GROTTOLI, S.; GHIGO, E.; ARVAT, E. Elderly subjects show severe impairment of dehydroepiandrosterone sulphate and reduced sensitivity of cortisol and aldosterone response to the stimulatory effect of $\mathrm{ACTH}(1-24)$. Clin Endocrinol (Oxf). v. Aug;55(2), p.259-65, 2001.

GIUS, D.; BOTERO, A.; SHAH, S.; CURRY H.A. Intracellular oxidation/reduction status in the regulation of transcription factors NF-KB and AP-1 Toxicol. Lett. v.106, p. 93-106. 1999.

GLIMCHER, M.J.; HODGE, A.J.; SCHMITT, F.O. Macromolecular aggregation states in relation to mineralization: the collagen-hydroxyapatite system as studied in vitro. Proc. Natl. Acad. Sci. v. 43, p. 860-6; 1957. 
GOSSET, P.; WALLAERT, B.; TONNEL, A.B.; FOURNEAU, C. Thiol regulation of the production of TNF-alpha, IL-6 and IL-8 by human alveolar macrophages Eur. Respir. J. v. 14, p. 98-105; 1999.

GOY-THOLLOT, I.; DECOSNE-JUNOT, C.; BONNET, J.M. Influence of aging on adrenal responsiveness in a population of eleven healthy beagles. Res Vet Sci. v. Apr;82(2), p.195-201, 2006.

GRANGER DN, RUTILI G, MCCORD JM. Superoxide radicals in feline intestinal ischemia. Gastroenterology. v. Jul;81(1), p.22-9, 1981.

GRAY ANATOMIA - Charles Mayo Gross, Ed. Guanabara-Koogan, Angelo Machado, Ed. Atheneu Koogan, 2002.

GREEN, P. G.; JÄNIG, W.; LEVINE, J. D. Negative feedback neuroendocrine control of inflammatory response in the rat is dependent on the sympathetic postganglionic neuron.J Neurosci. v.May 17(9), p.3234-8, 1997.

GRIENDLING, K. K.; SORESCU, D.; LASSEGUE, B.; USHIO-FUKAI, M. Modulation of protein kinase activity and gene expression by reactive oxygen species and their role in vascular physiology and pathophysiology. Arterioscler Thomb Vasc Biol. v. 20, p. 2175-2183. 2000.

GRIFFITH, O.W.; MEISTER, A. Potent and specific inhibition of glutathione synthesis by buthionine sulfoximine (S-n-butyl homocysteine sulfoximine). J. Biol. Chem. v. 254, p. 7558-7560; 1979.

GUPTA, A.; JAIN, G.K.; RAGHUBIR, R. A time course study for the development of an immunocompromised wound model, using hydrocortisone. J Pharmacol Toxicol Methods. v.41,:183-7, 1999.

GURLEK, A.; PITTELKOW, M.R.; KUMAR, R. Modulation of growth factor/cytokine

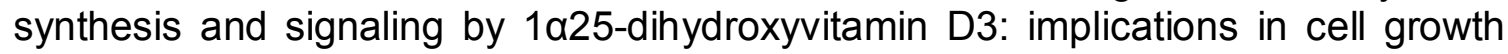
and differentiations Endocr. Rev. v. 23, p.763-86, 2002.

GUTTERIDGE, J.M.C. Lipid peroxidation: some problems and concepts. In Halliwell B (ed): Oxygen radicals and tissue injury. Proceedings of a Brook Lodge Symposium; 1987 Apr 27-29; Bethesda (MLD): Upjohn/Federation of American Societies for Experimental Biology, p. 9-19, 1988.

HACKER, H.; KARIN, M. Is NFKB2/p100 a direct activator of programmed cell death? Cancer Cell. v. 33, p.431-433; 2002.

HADDAD, J.J. Glutathione depletion is associated with augmenting a proinflammatory signal: Evidence for an antioxidant/pro-oxidant mechanism regulating cytokines in the alveolar epithelium. Cytokines Cell Mol Therap. v. 6, p.177-187, 2000. 
HADDAD, J.J.; CHOUDHARY, K.K.; LAND, S.C. The ex vivo differential expression of apoptosis signaling cofactors in the developing lung: Essential role of oxygenation during the transition from placental to pulmonary-based respiration. Biochem Biophys Res Commun. v. 281, p.311-316, 2001.

HADDAD, J.J.; LAND, S.C. O2-evoked regulation of HIF-1 $\alpha$ and NF-KB in perinatal lung epithelium requires glutathione biosynthesis Am. J. Physiol., Lung Cell Mol. Physiol. v. 278, p. L492-L503, 2000.

HADDAD, J.J.; LAND, S.C. O2-evoked regulation of HIF-1 $\alpha$ and NF-KB in perinatal lung epithelium requires glutathione biosynthesis. Am J Physiol Lung Cell Mol Physiol. v.278,p.L492-L503, 2000.

HADDAD, J.J.; LAND, S.C. Tarnow-Mordi WO, Zembala M, KowaLczyk D, Lauterbach $\mathrm{R}$ Immunopharmacological potential of selective phosphodiesterase inhibition. II. Evidence for the involvement of an inhibitory-kappaB/nuclear factorkappaB-sensitive pathway in alveolar epithelial cells. J Pharmacol Exp Ther. Feb. V.300(2), p.567-76, 2002.

HADDAD, J.J.; LAND, S.C. The differential expression of apoptosis factors in the alveolar epithelium is redox sensitive and requires NF-kB (RelA)-selective targeting. Biochem Biophys Res Commun. v.271, p.257-267, 2000.

HADDAD, J.J.; OLVER, R.E.; LAND, S.C. Antioxidant/pro-oxidant equilibrium regulates HIF-1 $\alpha$ and NF-KB redox sensitivity: Evidence for inhibition by glutathione oxidation in alveolar epithelial cells. J Biol Chem. v.275, p.21130-21139, 2000.

HADDAD, J.J.; SAFIEH-GARABEDIAN, B.; SAADÉ, N.E.; KANAAN, S.A.; LAND, S.C. Chemioxyexcitation ( $\triangle \mathrm{pO} 2 / \mathrm{ROS}$ ) dependent release of IL-1 $\beta$, IL-6 and TNF- $\alpha$ : Evidence of cytokines as oxygen-sensitive mediators in the alveolar epithelium. Cytokine. V.13, p.138-147, 2001.

HADDAD, J.J.; SAFIEH-GARABEDIAN, B.; SAADÉ, N.E.; LAND, S.C. Thiol regulation of pro-inflammatory cytokines reveals a novel immunopharmacological potential of glutathione in the alveolar epithelium. J Pharmacol Exp Therap. v. 296, p.996-1005, 2001.

HALLIWEL, B.; GUTTERIDGE, J. M. C. Free radical in biology and Medicine, 2nd ed. Clarendon Press, Oxford, 1989.

HALLIWELL, B.; GUTTERIDGE, J. M. C. Free Radical in biology and Medicine. Clarendon, Oxford. 1980.

HARMAN, D. Aging a theory based on free radical and radiation chemistry. J.Gerontol. v.11, p. 298-300, 1956. 
HARMAN, D. Free radical involvement in aging. Physiopathology and therapeutic implication. Drugs and Aging. v.1, p. 60-80, 1993.

HARMAN, D. Free radical theory of aging. Mutation Reserarch. v. 275, p. 275266, 1992.

HAYASHI, T.; UENO, Y.; OKAMOTO, T. Oxidoreductive regulation of nuclear factor K B. Involvement of a cellular reducing catalyst thioredoxin J. Biol. Chem. v. 268, p. 11380-11388, 1993.

HAYDEN, M.S.; GHOSH, S. Signaling to NFKB. Genes \& Development. v. 18, p. 2195-2224, 2004.

HAYES, J. D.; MACMAHON, M. Molecular basis for contribution of the antioxidant responsive element to cancer chemoprevention. Cancer Letters. v. 174, p.103-13; 2001.

HELLWEG, C.E.; ARENZ, A.; BOGNER, S.; SCHMITZ, C.; BAUMSTARK-KHAN, C. Activation of nuclear factor kappa B by different agents: influence of culture conditions in a cell-based assay.Ann N Y Acad Sci. v. Dec;1091, p.191-204, 2006

HENCH, P.S.; SLOCUMB, C.H.; BARNES, A.R.; SMITH, H.L.; POLLEY, H.F.; KENDALL, E.C. The effect of a hormone of the adrenal cortex, 17-hydroxy-11dehydrocorticosterone (compound $E$ ), on the acute phase of rheumatic fevers. Proceedings of the Staff Meetings of the Mayo Clinic. v.24, p.277-297, 1949.

HERSHKO, C. Mechanism of iron toxicity and its possible role in red cell membrane damage. Semin Hematol; v. 26, p. 277-85, 1989.

HIROTA, K.; MATSUI, M.; MURATA, M.; TAKASHIMA, Y. CHENG, F.S.; ITOH, T.; Nucleoredoxin, Glutaredoxin, and Thioredoxin Differentially Regulate NF-KB, AP-1, and CREB Activation in HEK293 Cells .Biochem. Biophys. Res. Commun. v. 274, p. $177-182,2000$.

HIROTA, K.; MURATA, M.; ITOH, T.; YODOI, J.; FUKUDA, K. An endogenous redox molecule, thioredoxin, regulates transactivation of epidermal growth factor receptor and activation of NF-kB by lysophosphatidic acid. FEBS Lett. v. 489 ,p. 134-138; 2001.

HIROTA, K.; MURATA, M.; SACHI, Y.; NAKAMURA, H.; TAKEUCHI, J.; MORI K. Distinct roles of thioredoxin in the cytoplasm and in the nucleus. A two-step mechanism of redox regulation of transcription factor NF-kappaB.J. Biol. Chem. v. 274, p. 27891-27897, 1999.

HO, E. Zinc deficiency, DNA damage and cancer risk. J Nutr Biochem.v. Oct; 15(10), p. 572-8, 2004. 
HOCHACHKA, P.W.; BUCK, L.T.; DOLL, C.J.; LAND, S.C. Unifying theory of hypoxia tolerance: Molecular/metabolic defense and rescue mechanisms for surviving oxygen lack. Proc Natl Acad Sci USA. v. 93, p.9493-9498, 1996.

HORÁKOVÁ, L.; STOLC, S. Antioxidant and pharmacodynamic effects of Pyridoindole Stobadine.(review). Gen. Pharmac. v 30, n 5, p. 625-638; 1998.

HORTON, R.; RICE-EVANS, C.; FULLER, B.J. The effects of iron-mediated oxidative stress in isolated renal cortical brush border membrane vesicles at normothermic and hypothermic temperatures. Free Radic Res Commun. v. 5: p. 267-75, 1989.

HSIEH, H. J.; LI, N. Q.; FRANGOS, J. A. Shear stress increases endothelial platelet, derived grow factor mRNA level Am. J. Physiol. v. 260, p. H642-646, 1991.

HUNG, C. T.; ALLEN, F. D.; POLLACK, S. R.; BRIGHTON, C. T. Intra-cellular $\mathrm{Ca} 2+$ are required in the real-time $\mathrm{Ca} 2+$ response of bone cells experiencing fluid flow. J. Biomech. v.29, p. 1411-1417, 1996.

HUTTER, D.; GREENE, J.J. Influence of the cellular redox state on NF-KBregulated gene expression J. Cell Physiol. v. 183, p. 45-52, 2000.

IGARASHI, A.; YAMAGUCHI, M. Great increase in bone $66 \mathrm{kDa}$ protein and osteocalcin at later stages with healing rat fractures: effect of zinc treatment. Int $\mathbf{J}$ Mol Med. v. Feb; 11(2), p. 223-8, 2003.

IGNATOWICZ, E.; RYBCZYNSKA, M. Some biochemical and pharmacological aspects of free radical-mediated tissue damage. Pol. J. Pharmacol. v. 46, p. 103114, 1994.

IQBAL, J.; ZAIDI, M. Molecular regulation of mechanotransduction.Biochem Biophys Res Commun. v. Mar 18;328(3), p. 751-5, 2005.

ISRAEL, N.; GOUGEROT-POCIDALO, M.A.; AILLET, F.; VIRELIZIER, J.L. Redox tatus of cells nfluences constitutive or induced NF-kappa B translocation and HIV long terminal repeat ctivity in human $\mathrm{T}$ and monocytic cell lines.J Immunol. v. Nov 15;149(10), p.3386-93, 1992.

JANSSEN-HEININGER, .M. POYNTER, M.E.; BAEUERLE, P.A. Recent advances torwards understanding redox mechanisms in the activation of nuclear factor Free Radic. Biol. Med. v. 28, p. 1317-1327, 2000.

JIANG, B.H.; SEMENZA, G.L.; BAUER, C.; MARTI, H.H. Hypoxia-inducible factor 1 levels vary exponentially over a physiologically relevant range of oxygen tension. Am J Physiol. v. 271, p. C1172-C1180, 1996. 
JIMENEZ, A.; CREISSEN, G.; KULAR, B.; FIRMIN. J.; ROBINSON, S.; VERHOEYEN, M.; MULLINEAUX, P. Changes in oxidative processes and components of the antioxidant system during tomato fruit ripening. Planta. $\mathrm{V}$. Mar;214(5), p. 751-8. 2001.

JIMENEZ, L.A.; THOMPSON, J.; BROWN, D.A.; RAHMAN, I.; ANTONICELLI, F.; DUFFIN, R. et al. Activation of NF-KB by PM10 Occurs via an Iron-Mediated Mechanism in the Absence of IKB Degradation Toxicol. Appl. Pharmacol. v. 166, p. 101-110, 2000.

JIMI, E.; GHOSH, S.; Role of nuclear factor-kappaB in the immune system and bone. Immunol Rev. v.Dec;08, p. 80-7, 2005.

JIN, D.Y.; CHAE, H.Z.; RHEE, S.G.; JEANG, K.T. Regulatory role for a novel human thioredoxin peroxidase in NF-kappaB activation. J. Biol. Chem. v. 272, p. 30952-30961, 1997.

JUNQUEIRA, U. L. C. \& JUNQUEIRA, S. M. M. L. Técnicas Básicas de Citologia e Histologia. Ed. Santos. $1^{\circ}$ Edição, 1984.

KARSENTY, G. The genetic transformation of bone biology. v. 13, No.23 Dec, p.3037-3051, 1999.

KARST, M.; GORNY, G.; GALVIN, R.J.; OURSLER, M.J. Roles of stromal cell RANKL, OPG, and M-CSF expression in biphasic TGF-beta regulation of osteoclast differentiation. J Cell Physiol. v. Jul;200(1), p. 99-106, 2004

KEANE, M.P.; STRIETER, R.M. The importance of balanced pro-inflammatory and anti-inflammatory mechanisms in diffuse lung disease. Respir. Res. v. 3:5-11, 2002.

KERR, J. F. R.; CURRIE, A. R. Apoptosis: a basic biological phenomenon with wide-ranging implications in tissue kinetics. Br J. Cancer, v. 26, p. 239-257, 1995. KHODR B, KHALIL Z. Modulation of inflammation by reactive oxygen species: implications for aging and tissue repair. Free Radic Biol Med. v. Jan 1;30(1), p.18, 2001.

KIMBLE, R.B.; KITAZAWA, R.; VANNICE, J.L.; PACIFICI, R. Persistent bonesparing effect of interleukin-1 receptor antagonist: a hypothesis on the role of IL-1 in ovariectomy-induced bone loss. Calcif Tissue Int. v. Oct;55(4), p.260-5, 1994

KLINGS, E.S.; FARBER, H.W. Role of free radicals in the pathogenesis of acute chest syndrome in sickle cell disease. Respir Res. v. 2, p. 280-285, 2001.

KOO, S.; KONIG, B. JR.; ALLEGRINI, S. JR.; YOSHIMOTO, M.; CARBONARI, M.J.; MITRI-LUIZ, F.F. Titanium implant osseointegration with calcium 
pyrophosphate in rabbits.J Biomed Mater Res B Appl Biomater. v. Feb;76(2), p. 373-80, 2006.

KUMAR, A.; TAKADA, Y.; BORIEK, A.M.; AGGARWAL, B.B. Nuclear factor-KB: its role in health and disease. Journal of Molecular Medicine. v.82, p. 434-448, 2004.

KUROKOUCHI, K.; JACOBS, C.R.; DONAHUE, H. J. Oscillating Fluid Flow Inhibits TNF-a-Induced NF-kappaB Activation via an IkappaB Kinase Pathway in Osteoblast-Like UMR106 Cells J. Biol. Chem. v. 276, Issue 16, p. 13499-13504, 2001.

LANG, C.H.; KUMAR, V.; LIU, X.; FROST, R.A.; VARY, T.C. IGF-I induced phosphorylation of S6K1 and 4E-BP1 in heart is impaired by acute alcohol intoxication. Alcohol Clin Exp Res. v.Mar;27(3), p.485-94, 2003.

LANYON, L. E. Osteocytes, strain detection, bone modeling and remodeling. Calcif.Tissue Int.v. 53, p. S102-107, 1993.

LAUGERO, K.D. Reinterpretation of basal glucocorticoid feedback: implications to behavioral and metabolic disease. Vitam. Horm. v. 69, p.1-29, 2004.

LEAN, J. M.; JAGER, T. J.; CHAMBERS, T. J.; CHOW, J. W. Increased insulin-like growth factor I mRNA expression in rat osteocytes in response to mechanical stress. Am. J. Physol. v. 268,p. E318-327, 1995.

LEE P.J; JIANG, B.H; CHIN, B.Y; IYER, N.V; ALAM, J; SEMENZA, G.L.; CHOI, A.M.; Hypoxia-inducible factor-1 mediates transcriptional activation of the heme oxygenase-1 gene in response to hypoxia. J Biol Chem. v. 272, p. 5375-5381, 1997.

LEE, B.L.; LEE, H.S.; JUNG, J.; CHO, S.J.; CHUNG, H.Y.; KIM, W.H. et al. Nuclear factor-kB activation correlates with better prognosis and Akt activation in human gastric cancer. Clinical Cancer Research. v.11 (17), p. 2518-2525, 2005.

LEGRAND-POELS, S.; ZECCHINON, L.; PIRET, B.; SCHOONBROODT, S.; PIETTE, J. Involvement of different transduction pathways in NF-KB activation by several inducers Free Radic. Res. v. 27, p. 301-309, 1997.

LEHNINGER, A. B. et al. Princípios de bioquímica. Ed. Savier. 1986.

LEIBOVICH, S.J.; ROSS, R. The role of the macrophage in wound repair. A study with hydrocortisone and antimacrophage serum. Am J Pathol. v.78, v.71-100, 1975. 
LEVIEUX, A.; LEVIEUX, D. Immunoquantitation of rat erythocyte superoxide dismutase: its use in copper deficiency. Free Rad. Biol. Med. v. 11, p. 589-595, 1991.

LI, X.; STARK, G. R. NFkB-dependent signaling pathways. Experimental Hematology. v. 30, p. 285-296, 2002.

LIPECKA, K. Therapeutic application of superoxide dismutases as antiphlogistic agent Pol. Tyg. Lek. v. 44, p. 339-340, 1989.

LITOVSKY, S.H.; ANTZELEVITCH, C. Transient outward current prominent in canine ventricular epicardium but not endocardium. Circ Res v. 62, p.116-26, 1988.

LOSEL, R.M.; FALKENSTEIN, E.; FEURING, M.; SCHULTZ, A.; TILLMANN, H.C.; ROSSOL-HASEROTH, K. Nongenomic steroid action: controversies, questions, and answers. Physiol Rev. v. 83(3), p.965-1016, 2003.

MACHLIN, L. J.; BENDICH, A. Free radical tissue damage: protective role of antioxidant nutrients. FASEB J. v.71, p. 441-445, 1987.

MAELLARO, E.; CASINI, A. F.; DEL BELLO; B.; COMPORTI, M. Lipid peroxidation and antioxidant systems in the liver injury produced by glutatione depleting agents. Biochem. Pharmacol. v. 39, p. 1513-1521, 1990.

MAKINO, S.; HASHIMOTO, K.; GOLD, P.W. Multiple feedback mechanisms activating corticotropin-releasing hormone system in the brain during stress. Pharmacol Biochem Behav. ;v. 73(1), p.147-58, 2002.

MARK, A. F. T; QIN, L.; HUNG, L. K.; CHENG, C. W.; TIN, C. F. A histomorphometric observation of flows in cortical bone under dynamic loading. Microvasc. Res. v. 59, p. 290-300, 2000.

MASON RJ, WILLIAMS MC. Type II alveolar cell: Defender of the alveolus. Am Rev Respir Dis.115:81-91; 1977.

MATTHEWS, J.R.; HAY, R.T. Regulation of the DNA binding activity of NF-kappa B. Int J Biochem Cell Biol. v. Sep;27(9), p. 865-79, 1995.

MAXWELL, P.H.; RATCLIFFE, P.J. Oxygen sensors and angiogenesis. Semin Cell Dev Biol. v. 13, p. 29-37, 2002.

MCKAY, L.I.; CIDLOWSKI, J.A. Cross-talk between nuclear factor-kappa B and the steroid Proc Natl Acad Sci U S A. v.Oct 24;97(22), p.11893-11898, 2000.

MEISTER, A. Glutathione metabolism and its selective modification. J. Biol. Chem. v.263, p. 17205-17208, 1988. 
MELLO FILHO, A.C.; HOFFMAN, M.E.; MENEGHINI, R. Cell killing and DNA damage by hydrogen peroxide are mediated by intracellular iron. Biochem J. v. 218, 273-51, 1983.

MINOTTI, G.; AUST, S.D. The requirement for iron (III) in the initiation of lipid peroxidation by iron (II) and hydrogen peroxide. J Biol Chem. v. 262, p. 1.098-104, 1987.

MOLITOR, J.A.; BALLARD, D.W.; GREENE, W.C. Kappa B-specific DNA binding proteins are differentially inhibited by enhancer mutations and biological oxidation. New Biol. v. 3, p. 987-996, 1991.

MONTESINOS, M.C.; DESAI, A.; CRONSTEIN, B.N.Suppression of inflammation by low-dose methotrexate is mediated by adenosine $A 2 A$ receptor but not A3 receptor activation in thioglycollate-induced peritonitis. Arthritis Res Ther. Epub Mar 62006.

MOYNAGH, P.N. The NFkB pathway. Journal of Cell Science. v. 118, p. 43894392, 2005.

MUNDAY, R.; WINTERBOUM, C. C. Reduced glutathione in combination with superoxide dismutases as an important biological antioxidant defense mechanism. Biochem. Pharmacol. v. 38, p. 4349-4352; 1989.

NARISAWA, S.; FRÖHLANDER, N.; MILLÁN, J.L. Inactivation of two mouse alkaline phosphatase genes and establishment of a model of infantile hypophosphatasia. Dev. Dyn. v. 208, p. 432-446, 1997.

NESIN, M.; CUNNINGHAM-RUNDLES, S. Cytokines and neonates. Am. J. Perinatol. V. 17, p. 393-404, 2000.

NIE, Z.; YUN, M.; MARY, F.; RYBAK, L.; MARCUZZI, A.; REN, H.; STILES, G. L.; RAMKUMAR, V. Oxidative Stress Increases A1 Adenosine Receptor Expression by Activating Nuclear Factor KB. Mol Phamacol. v. 53, p. 663-669, 1998.

NOMURA, N.; TAKANO,Y. Molecular events cased by machanical stress in bone. Mat. Biol. v.19, p.91-96, 2000.

NOYERS, F.R.; DE LUCAS, J.L.; TORVIK, P.J. Biomechanics ot anterior Fracture of the intercondylar eminence of the tibia.J Bone Joint Surg. v. 52 A, p. 16771684, 1993.

OGAWA, H.; YU, R.T.; HARAGUCHI, T.; HIRAOKA, Y.; NAKATANI, Y.; MOROHASHI, K. Nuclear structure-associated TIF2 recruits glucocorticoid receptor and its target DNA. Biochem Biophys Res Commun. v.320(1), p.21825, 2004. 
OLDBERG, A.; FRAZÉM, A.; HEINEGÅRD, D. Cloning and sequence analysis of rat bone sialoprotein (osteopontin) cDNA reveals an Arg-Gly-Asp cel-blinding sequence. Proc. Natl. Acad. Sci. USA. v. 83, p. 8819-8823, 1986.

PABLOS, A. B. AVALIAÇÃO HISTOLÓGICA DA INFLUÊNCIA DE DUAS DROGAS ANTIINFLAMATÓRIAS NÃO ESTEROIDAIS SOBRE A REPARAÇÃO ÓSSEA PERIIMPLANTAR. Tese apresentada ao Centro de Pós-Graduação / CPO São Leopoldo Mandic, para obtenção do grau de Doutor em Ciências Odontológicas. Área de Concentração: Implantodontia 2006.

PARMENTIER, M.; HIRANI, N.; RAHMAN, I.; DONALDSON, W.; MACNEE, W.; ANTONICELLI, F. Regulation of lipopolysaccharide-mediated interleukin-1beta release by $\mathrm{N}$-acetylcysteine in THP-1 cells. Eur. Respir. J. v.16, p. 933-939, 2000.

PEERS, C.; KEMP, P.J. Acute oxygen sensing: Diverse but convergent mechanisms in airway and arterial chemoreceptors. Respir Res. v. 2, p.145-149, 2001.

PERKINS, N.D. NFKB: tumor promoter or suppressor? Trends in Cell Biology. v. 14(2), p. 64-69, 2004.

PIERCE, G. F.; MUSTOE, T. A.; LINGELBACH, J.; MASAKOWSKI, V.R.; GRAMATES, P.; DEUEL, T.F. Transforming growth factor beta reverses the glucocorticoid-induced wound-healing deficit in rats: possible regulation in macrophages by platelet-derived growth factor. Proc Natl Acad Sci U S A. v. 86, p. 2229-33, 1989.

PIERCE, R.; SASAKI, T.; TIMPL, R.; CHU, M.L. Werner S. Differential regulation of fibulin, tenascin- $C$, and nidrogen expression during wound healing normal and glucocorticoid-treated mice. Exp Cell Res. v. 222, p.111-6, 1996.

PITSILLIDES, A. A.; RAWLINSON, S. C.; SUSWILLO, R .F.; BOURRIN, S.; ZAMAN, G.; LANYON, L. E. Mechanical strain-induce NO production by bone cells: a possible role in adaptive bone remodeling? FASEB J. v.9, p.1614-1622, 1995.

POMPEIA, C.; LIMA, T.; CURI, R. (Review) Arachidonic acid cytotoxicity: can arachidonic acid be a physiological mediator of cell death? Cell Biochem Funct. $v$. Jun;21(2), p.97-104, 2003.

PORWOL, T.; EHLEBEN, W.; BRAND, V.; ACKER, H. Tissue oxygen sensor function of NADPH oxidase isoforms, an unusual cytochrome aa3 and reactive oxygen species. Respir Physiol. v.128, p.331-348, 2001.

POWELL, S. R. Zinc and Health: Current Status and Future Directions. The Antioxidant Properties of Zinc. J. Nutr. v. 130, p.1447S-1454S, 2000. 
PRABHAKAR, N.R.; OVERHOLT, J. L. Cellular mechanisms of oxygen sensing at the carotid body: Heme proteins and ion channels. Respir Physiol. v.122, p.209221, 2000.

QIN, J.; CLORE, G.M.; KENNEDY, W.M.P.; HUTH, J.R.; GRONENBORN, A.M. Solution structure of human thioredoxin in a mixed disulfide intermediate complex with its target peptide from the transcription factor NFKB. Structure 3, p. 289-297, 1995.

RAHMAN, I. Regulation of nuclear factor-kB, activator protein-1, and glutathione levels by tumor necrosis factor- $\alpha$ and dexamethasone in alveolar epithelial cells Biochem. Pharmacol. v. 60, p. 1041-1049; 2000.

RAHMAN, I.; MACNEE, W. Oxidative stress and regulation of glutathione in lung inflammation Eur. Respir. J. v. 16, p. 534-554, 2000.

RAHMAN, I.; MULIE, B.; GILMOUR, P.S.; WATCHORN, T.; DONALDSON, K.; JEFFERY, P. K. Oxidant-mediated lung epithelial cell tolerance: the role of intracellular glutathione and nuclear factor-kappaB1 .Biochem. Pharmacol. v. 62, p. 787-794, 2001.

RAHMAN, I.; MULIER, B.; GILMOUR, P. S.; WATCHORN, T.; DONADLSON, K.; JEFFERY, P. K.; MACNEE, W. Oxidant-mediated lung epithelial cell tolerance: The role of intracellular glutathione and nuclear factor-kB. Biochem Pharmacol. v. 62, p. 787-794, 2001.

RAVI, R.; BEDI, A. NFKB in cancer- a friend turned foe. Drug. Resistance Updates. V. 7, p. 53-67, 2004.

RAWLINSON, S. C.; EL-HAJ, A. J.; MINTER, S. L.; TAVARES, I. A.; BENNETT, A.; LANYON, L. E. Loading-related increases in prostaglandin production in cores of adult canine cancellous bone in vitro: a role for prostacyclin in adaptive bone remodeling? J. Bone Miner. Res. v. 6, p. 1345-1351; 1991.

REMACLE, J.; RAES, M.; TOUSSAINT, O.; RENARD, P.; RAO, G. Low levels of reactive oxygen species as modulators of cell function. Mutat Res. Feb. v. 316(3), p.103-22. 1995.

RHEE, S.G.; BAE, Y.S.; LEE, S.R.; KWON, J. Hydrogen peroxide: a key messenger that modulates protein phosphorylation through cysteine oxidation. Sci. Stke. [Electronic Resource] E1; 2000.

RICHALET, J. P. Oxygen sensors in the organism: Examples of regulation under altitude hypoxia in mammals. Comp. Biochem. Physio.I A. Physiol. v.118, p. 914, 1997. 
RIDDICK, C. A.; RING, W.L.; BAKE, J.R.; HODULIK, C.R.; BIGBY, T.D. Bigby, Dexamethasone increases expression of 5-lipoxygenase and its activating protein in human monocytes and THP-1 cells, Eur. J. Biochem. v. 246, p. 112-118, 1997.

RISSMAN, R. A.; POON, W. W.; BLURTON-JONES, M.; ODDO, S.; TORP, R.; VITEK, M. P.; LAFERLA, F. M.; TROY, R. T.; COTMAN, C. W. Caspase-cleavage of tau is an early event in Alzheimer disease tangle pathology J. Clin. Invest. V. 114, p.121-130, 2004.

$\mathrm{ROACH}, \mathrm{H}$. I. Trans-differentiation of hypertrophic chondrocytes into cells capable of producing a mineralized bone matrix. Bone Miner.Res. v.19, p. 1-20; 1992.

ROBBINS, L. S. Patologia estrutural e funcional. Rio de Janeiro: Guanabara Koogan, 4. edição, 1991.

ROBINSON, M. J.; COBB, M. H. Mitogen-activated protein kinase pathways. Curr. Opion.Cell Biol.v. 9, p. 180-6, 1997.

RODRÍGUEZ, M.; TRISTANO, A.; PLÁCERES, F. Expresión del ligando del receptor activador Nf-kB (Rankl) en los fibroblastos de la membrana sinovial de pacientes con artritis reumatoide.Vitae: Academia Biomédica Digital, $\mathrm{N}^{\circ}$. 14, 9 pags 2003.

ROONEY, S. A.; YOUNG, S.L.; MENDELSON, C.R. Molecular and cellular processing of lung surfactant. FASEB J. v. 8, p.957-967, 1994.

ROSS, D. Glutathione, free radical and chemotherapeutic agents. Mechanisms of free radial induced toxicity and glutathione dependent protection. Pharmacol.Ther. v. 37, p. 231-249, 1988.

ROSS, D.; MOLDEUS, P. Antioxidant defense systems and oxidative stress. In Vigo-Pelfrey C (ed): Membrane lipid oxidation. 1th ed. Boca Raton, CRC Press, p. 151-70; 1991.

ROSS, R.; RAINES, W.; BOWEN-POPE D. F. The biology platelet-derived growth factor. Cell. v. 46, p. 155-169, 1986.

ROUVEIX, B. Clinical pharmacology of cytokines. Eur Cytokine Netw.v. 8, p. 291300, 1997.

RUBIN, C.T.; LANYON, L.E.; Regulation of bone formation by applied dynamic loads.J Bone Joint Surg Am. v. Mar;66(3), p. 397-402, 1984.

RUDDELL, C. L. Hydroxyethyl methacrylate combined with polyethylene glycol 400 and water; and embedding medium for routine 1-2 micron sectioning. Stain. Technol. v. 42, p. 119-123, 1967. 
SADIKOT, R.T.; JANSEN, E.D.; BLACKWELL, T.R.; ZOIA, O.; YULL, F.; CHRISTMAN, J.W.; BLACKWELL, T.S. High-dose dexamethasone accentuates nuclear factor-kappa $b$ activation in endotoxin-treated mice. Am J Respir Crit Care Med. v. Sep 1;164(5), p.873-8, 2001.

SAIDENBERG-KERMANAC'H, N.; CORRADO, A.; LEMEITER, D.; DEVERNEJOUL, M.C.; BOISSIER, M.C.; COHEN-SOLAL, M.E. TNF-alpha antibodies and osteoprotegerin decrease systemic bone loss associated with inflammation through distinct mechanisms in collagen-induced arthritis. Bone. v.Nov;35(5), p.1200-7, 2004.

SAKLATVALA, J. Glucocorticoids: do we know how they work? Arthritis Res. v. 4(3), p.146-50, 2002.

SALCEDA, S.; CARO, J. Hypoxia-inducible factor-1a (HIF-1a) protein is rapidly degraded by the ubiquitin-proteasome system under normoxic conditions: Its stabilization by hypoxia depends on redox-induced changes. J Biol Chem. v. 272, p.22642-22647, 1997.

SALLES, M. B. Micro-elementos funcionais alterando a biocompatibilidade do polímero de poliuretana de mamona (POLIOL) em enxertos ósseos: estudo desenvolvido em cães. São Paulo, 2001. (Tese de Mestrado Instituto de Ciências Biomédicas da Univ. de São Paulo).

SATO, M.; OCHI, T.; NAKASE, T. Mechanical tension-stress induces expresión of BMP2 and -4, but not BMP-6, -7 and GDF-5 mRNA, during distraction osteogenesis. J. Bone Miner. Res. v. 14, p. 1084-1095; 1999.

SATO, M.; YASUI, N.; NAKASE, T. Expression of bone matrix proteins mRNA during distraction osteogenesis . J. Bone Miner. Res. v. 13, p. 1221-1231, 1998. SAUGSTAD, O.D. Oxygen radicals and pulmonary damage. Pediatric Pulmonol. v. 1, p.167-175, 1985.

SCHENK, R. [ON THE HISTOLOGICAL PROCESSING OF UNDECALCIFIED BONE.] Acta Anat (Basel). v. 60, p. 3-19, 1965.

SCHNEIDER, N.; LANZ, S.; RAME, R.; SCHAEFER, D.;GOPPELT-STRUEBE, M. Up-regulation of cyclooxygenase-1 in neuroblastoma cell lines by retinoic acid and corticosteroids, J. Neurochem. v. 77, p. 416-424, 2001.

SCHRECK, R.; ALBERMANN, K.; BAEUERLE, P. A. Nuclear factor kB: An oxidative stress-responsive transcription factor of eukaryotic cells. Free Radic Res Commun. v. 17, p. 221-237, 1992.

SCHUBERT, M. A.; WIGGINS, M. J.; DEFIFE, K. M.; HILTNER, A.; ANDERSON, J. M. Vitamin $E$ as an antioxidant for ply(etheryrethane urea): in vivo studes. In: Jornal of Biomedical Materials Reserch, v. 32, p. 493-504, 1996. 
SCHUCHMANN, M.; GALLE, P.R. Dead or alive- NFKB, the guardian which tips the balance. Journal of Hepatology, v. 36, p. 827-828, 2002.

SEN C. K. The general case for redox control of wound repair. Wound Rep. Reg. v. 11, p. 431-438, 2003.

SEN C.K. Cellular thiols and redox-regulated signal transduction. Curr Top Cell Regul. v. 36, p.1-30, 2000.

SEN C.K. Glutathione homeostasis in response to exercise training and nutritional supplements Mol. Cell Biochem. v. 16, p. 31-42, 1999.

SEN, C.K. Redox Signaling and the Emerging Therapeutic Potential of Thiol Antioxidants. Biochem Pharmacol. v. 55, p. 1747-1758, 1998.

SEN, C.K., PACKER, L. Redox cell biology and genetics. Part A. New York: Academic Press, 2002.

SEN, C.K.; PACKER, L. Antioxidant and redox regulation of gene transcription. FASEB J. v. 10, p.709-720, 1996.

SHAN, X, AW, T.Y.; Jones, D. P. Glutathione-dependent protection against oxidative injury. Pharmacol Ther. v. 47, p. 61-71, 1990.

SHER, L.; OQUENDO, M.A.; GALFALVY, H.C.; COOPER, T.B.; MANN, J.J. Age effects on cortisol levels in depressed patients with and without comorbid posttraumatic stress disorder, and healthy volunteers. J Affect Disord. v. Oct 1;82(1), p.53-9, 2004.

SHIVAKUMAR, K.; KUMAR, B.P. Magnesium deficiency enhances oxidative stress and collagen synthesis in vivo in the aorta of rats. Int $\mathbf{J}$ Biochem Cell Biol. v. Nov;29(11), p.1273-8, 1997.

SIDHU, P.; GARG, M.L.; DHAWAN, D.K. Protective effects of zinc on oxidative stress enzymes in liver of protein-deficient rats. Drug Chem Toxicol. v. 28(2):211302005.

SORRELLS, S.; F.; SAPOSLSK, R. M. An inflammatory review of glucocorticoid actions in the CNS. Brain Behav Immun. v.Mar;21(3), p.259-72, 2007.

STADNYK, A. W.; GAULDIER, J. The acute phases protein response during parasitic infection. Parasitol. Today. v. 7, p. A7-A12, 1991.

STARKE-REED, P. E.; OLIVER, C. N. Protein oxidantion and proteolysis during aging and oxidative stress. Archiv. Biochem. Biophys. v. 275, p. 559-567, 1989.

SUN, Y.; OBERLEY, L.W. Redox regulation of transcriptional activators Free Radic. Biol. Med. v.21, p. 335-348, 1996. 
TAKENAKA, A.; SHIMOGAKI, H.;MIZUNO.;Y, GOTO, A.; GOTO, K.; KAWAIDA, N.; GOHJI, K.; ARAKAWA, S.; MATSUMOTO, O. [VAB-6 chemotherapy of advanced testicular cancers-its efficacy and limitation] Nippon Hinyokika Gakkai Zasshi. v.Oct;82(10),p.1620-6,1991.

TANAKA, C.; KAMATA, H.; TAKESHITA, H.; YAGISAWA, H.; Hirata, H. Redox Regulation of Lipopolysaccharide(LPS)-Induced Interleukin-8 (IL-8) Gene Expression Mediated by NFKB and AP-1 in Human Astrocytoma U373 Cells . Biochem. Biophys. Res. Commun. v. 232, p. 568-573, 1997.

TANAKA, T.; NAKAMURA, H.; NISHIYAMA, A.; HOSOI, F.; MASUTANI, H.; WADA, $H$. Redox regulation by thioredoxin superfamily: Protection against oxidative stress and aging Free Radic. Res. v. 33, p. 851-855, 2001.

TAYLOR, A.F.; SAUNDERS, M.M.; SHINGLE, D.L.; CIMBALA, J.M.; ZHOU, Z.; DONAHUE, H.J. Mechanically stimulated osteocytes regulate osteoblastic activity via gap junctions. Am J Physiol Cell Physiol. v. Jan;292(1), p. C545-52. Epub 2006 Aug 2, 2007.

TEHEMAR, S. H. Factors affecting heat generation during implants site preparation: a review of biologic observations and future considerations. Int j. Oral Maxillofac Implants. v. 14, p.127-136, 1999.

TEWES, F.; BOL, G.F.; BRIGELIUS-FLOHE, R. Thiol modulation inhibits the interleukin (IL)-1-mediated activation of an IL-1 receptor-associated protein kinase and NF-kappa B. Eur. J. Immunol. v. 27, p. 3015-3021, 1997.

THOMAS, C. E.; REED, D. J. Radical-induced inactivation of kidney NaK-ATPase: Sensityvity to membrane lipid peroxidation and the protective effects of vitamin $\mathrm{E}$. Archiv. Biochem. Biophys. v.15, p. 96-105, 1990.

TOLEDANO, M. B.; LEONARD, W.J. Modulation of transcription factor NF-kappa B binding activity by oxidation-reduction in vitro Proc. Natl. Acad Sci. U. S. A. v. 88, p. 4328-4332, 1991.

TOSH, D.; SLACK, W.M.J. How cells change their phenotype. Nature Reviews/ Molecular Cell Biology. v. 3 march, 187-194, 2002.

TURNER, C.H.; FORWOOD, M.R.; OTTER, M.W.: Mechanotransduction in bone: Do bone cells act as sensors of fluid flow? FASEB J. v. 8, p. 875-878, 1994.

UDIPI, K.; ORNBERG, R.L.; THURMOND II, B.K.; SETTLE, S.T.; FORSTER, D.; RILEY,D. Modification of inflammatory response to implanted biomedical materials in vivo by surface bound superoxide dismutases mimics. Biomed. Mater. Res, v. 51, p. 549-560, 2000. 
ULLRICH, S.; BERCHTOLD, S.; RANTA, F.; SEEBOHM, G.; HENKE, G.; LUPESCU, A.; MACK, A.F.; CHAO, C.M.; SU, J.; NITSCHKE, R.; ALEXANDER, D.; FRIEDRICH, B.; WULFF, P.; KUHL, D.; LANG, F. Serum- and glucocorticoidinducible kinase 1 (SGK1) mediates glucocorticoid-induced inhibition of insulin secretion. Diabetes. v. Apr;54(4), p.1090-9, 2005.

VALLE-BLAZQUEZ, M.; LUQUE, I.; COLLANTES, E.; ARANDA, E.; SOLANA, R.; PENA, J. Cellular redox status influences both cytotoxic and NF-kappa B activation in natural killer cells Immunology. v. 90, p. 455-460, 1997.

VAN DER VLIET, A.; CROSS, C.E. Oxidants, nitrosants and the lung. Am J Med. v. 109, p.398-421, 2000.

WANG, F. S.; WANG, C. J.; SHEEN-CHEN, S. M.; KUO, Y. R.; CHEN, R. F.; YANG, K. D. Superoxide mediates shock wave induction of ERK-dependent osteogenic transcription toward osteoprogenitors. J. Biol. Chem. v. 277, p. 109317, 2002.

WANG, G.L.; SEMENZA, G.L. Purification and characterization of hypoxiainducible factor 1. J Biol Chem. v. 270, p.1230-1237, 1995.

WANG, Y.C.; LIN, R.K.; TAN, Y.H.; CHEN, J.T.; CHEN, C.Y.; WANG, Y.C. WildType p53 Overexpression and Its Correlation With Mdm2 and p14ARF Alterations: An Alternative Pathway to Non-Small-Cell Lung Cancer. Journal of Clinical Oncology, v. 23(1), p.154-164, 2005.

WARIS, G.; HUH, K. W.; SIDDIQUI, A. Mitochondrially associated hepatitis B virus $X$ protein constitutively activates transcription factors STAT-3 and NF-kappa B via oxidative stress. Molecular And Cellular Biology. v. 21, p. 7721-7730, 2001.

WAYMIRE, K.G.; MAHUREN, J.D.; JAJE, J.M.; GUILARTE, T.R.; COBURN, S.P.; MACGREGOR, G.R. Mice lacking tissue non-specific alkaline phosphatase die from seizures due to defective metabolism of vitamin B-6. Nat. Genet. v. 11, p. 4551, 1995.

WAYNER, D. D. M.; BURTON, G. W.; INGOLD, K. U. The relative contributions of vitamin $\mathrm{E}$, urate, ascorbate and proteins to the total peroxyl radical-trapping an tioxidant activity of human blood plasma. Biochim. Biophys Acta. v. 924, p. 408419, 1987.

WAYPA, G.B.; CHANDEL, N.S.; SCHUMACKER, P.T. Model for hypoxic pulmonary vasoconstriction involving mitochondrial oxygen sensing. Circ Res.v. 88, p.1259-1266, 2001

WEINGARTEN, P.; BERMAK, J.; ZHOU, Q. Y. Evidence for non-oxidative dopamine cytotoxicity: potent activation of NF-kappa B and lack of protection by anti-oxidants. J. of Neurochemistry. V. 76, p. 1794-1804, 2001. 
WENGER R.H. Mammalian oxygen sensing, signaling and gene regulation. J Exp Biol. v. 203, p.1253-1263, 2000.

WENGER, R.H.; GASSMANN, M. Oxygen(es) and the hypoxia-inducible factor-1. Biol Chem. v. 378, p. 609-616, 1997.

WESTEN, H.; MUCK, K.F.; POST, L. Enzyme histochemistryon bone marrow sections after embedding in methacrylate at low temperature. Histochemistry, $v$. 70, p. 95-105, 1981.

WESTENDO, R. P.; SHATROV, M. O; SCHULZE-OSTHOFF, K.; FRANK, R.; KRAFT, M.; LOS, M.; KRAMMER, P. H.; DRÖGE, W.; LEHMANN, V. HIV-1 Tat potentiates TNF-induced NF-kappa $B$ activation and cytotoxicity by altering the cellular redox state The EMBO Journal. v. 14, v. 546-554, 1995.

WHYTE, M.P. Hyphophosphatasia and the role of alkaline phosphadase in skeletal mineralization. Endocrin. Rev. v.15, p. 439-461, 1994.

WIDÉN, C.; JAN-ÅKE, G.; ANN-CHARLOTTE, WIKSTRÖM, A.C. Cytosolic glucocorticoid receptor interaction with nuclear factor-kB proteins in rat liver cells. Biochem. J v.373,p. 211-220, 2003.

WYLLIE, A. H.; KERR, J. F. R.; CURRIE, J. F. R. Cell death: the significance of apoptosis . Int. Rev. Cytol. New York, p. 251-306,1980.

YAMAMOTO, Y.; GAYNOR, R. B. IKB Kinases:key regulators of the NFkB pathway. Trends in Biochemical Sciences; v.29 (2), p. 72-79, 2004.

YANG, L.; CRANSON, D.; TRINKAUS-RANDALL, V. Cellular injury induces activation of MAPK via P2Y receptors. Cell Biochem. v. Apr 1;91(5), p.93850:2004.

YANG,C.M.; DAVIS,C.W.; ARCHER R.G.; Immunohistochemistry of Markers IN Techovit $9100 \AA$ New embedded undecalcifield bone sections. Eur Cell Mater. v. Dec 31;6, p. 57-71, 2003.

YASUI, N.; SATO, M.; OCHI, T.; KIMURA, T.; KAWAHATA, H.; KITAMURA, Y.; NOMURA, S. Three modes of ossification during distraction osteogenesis in the rat. J Bone Joint Surg Br. V. Sep;79(5), p.824-30, 1997.

YELLOWLEY, C. E.; LI, Z.; ZHOU, Z.; JACOBS, C.R.; DONAHUE, H.J. Functional gap junctions between osteocytic and osteoblastic cells. J Bone Miner Res.v. Feb;15(2), p.209-17, 2000.

YOSHIDA, Y.; MARUYAMA, M.; FUJITA, T. Reactive oxygen intermediates stimulate interleukin-6 production in human bronchial epithelial cells. Am $\mathbf{J}$ Physiol. v. 276, p. L900-L908, 1999. 
YOSHIMOTO, M.; ALLEGRINI, S.JR.; MANGINI, E.A.; BRESSIANI, J.C.; BRESSIANI, A.H.A. MAGALHÃES, J.C.A.;SALLES,M.B. Utilização de soft-laser e de um composto polivitamínico na reparação da estrutura nervosa, após a cirurgia de lateralização do nervo laveolar inferior, um estudo histológico comparativo. $5^{\circ}$ Encontro de Mestres em cirurgia e Prótese sobre Implantes. Implat. News. v.3,n 6, p.635-637, 2006.

YOU, L.; COWIN, S.C.; SCHAFFLER, M.B.; WEINBAUM, S. A model for strain amplification in the actin cytoskeleton of osteocytes due to fluid drag on pericellular matrix. J Biomech. v. Nov;34(11), p. 1375-86, 2001.

YOU, L.D.; WEINBAUM, S.; COWIN, S.C.; SCHAFFLER, M.B. Ultrastructure of the osteocyte process and its pericellular matrix. Anat Rec A Discov Mol Cell Evol Biol. v. Jun;278(2), p.505-13, 2004.

ZHAO, Q.; PANG, J.; FAVATA, M.F.; TRZASKOS, J.M. Receptor density dictates the behavior of a subset of steroid ligands in glucocorticoid receptor-mediated transrepression. Int Immunopharmacol. v.Dec;3(13-14), p.1803-17, 2003.

ZHU, H.; BUNN, H.F. Signal transduction. How do cells sense oxygen? Science. v. 292, p.449-451, 2001.

ZREIQAT, H.; EVANS, P.; HOWLETT, C.R. Effect of surface chemical modification of bioceramic on phenotype of human bone-derived cells. J Biomed Mater Res. v. Mar 15;44(4), p.389-96, 1999.

ZREIQAT, H.; VALENZUELA, S.M.; NISSAN, B.B.; ROEST, R.; KNABE, C.; RADLANSKI, R.J.; RENZ, H.; EVANS, P.J. The effect of surface chemistry modification of titanium alloy on signaling pathways in human osteoblasts. Biomaterials. v.Dec;26(36), p.7579-86, 2005. 